Pablo Agnese 
The Anselmo Rubiralta Center for Globalization and Strategy aims to be an international benchmark for companies, universities, business schools and governments. It promotes the exchange of ideas in the area of globalization and international strategy.

The Center's main objectives are to:

- Develop a conceptual structure that will help companies to understand and manage the impact of globalization and develop strategies of internationalization;

- Generate and disseminate new knowledge in this field;

- Develop new, high-quality teaching materials.

www.iese.edu/globalcenter 


\title{
JAPAN AND HER DEALINGS WITH OFFSHORING: AN EMPIRICAL ANALYSIS WITH AGGREGATE DATA
}

\author{
Pablo Agnese ${ }^{1}$
}

\begin{abstract}
First moves towards a real understanding of the offshoring phenomenon date back to very recent times, with employment and productivity effects occupying much of the literature around the subject. In particular for Japan, the studies conducted so far focus on the disaggregate level and put the stress on the productivity side alone. Here I carry out both the analyses of the employment and productivity effects at the aggregate level of the industry, covering the years 1980-2005. Moreover, I consider all industries within the economy and take account of both materials and services offshoring. The results presented here suggest that we can expect a positive effect of services offshoring on employment, and a positive effect of materials offshoring on the growth rate of productivity.
\end{abstract}

Classification JEL: F16, J23, 047

Keywords: Japan, offshoring, employment, productivity.

${ }^{1}$ IESE Business School and Autonomous University of Barcelona 


\section{JAPAN AND HER DEALINGS WITH OFFSHORING: AN EMPIRICAL ANALYSIS WITH AGGREGATE DATA'}

\section{Introduction}

It is now no secret that Japan has been lagging behind other countries for the past twenty years, running into an uncertain post-bubble era that seems to stretch to unknown horizons. Many have been the hypotheses thrown into the debate; few have been the definitive answers. Explanations range from those related to low productivity rates and demographic changes, to those identifying monetary factors as main determinants of the current state of affairs. It is certainly not my goal to pursue an answer to this mystery here. Rather, it is the effects of the "new" offshoring hype over this particular economy that I will be looking into. Particularly, I am interested in the employment and productivity effects of offshoring on the Japanese labor market.

The most recent and heated discussions about economic policy worldwide have to do with offshoring. The mainstream media is repeatedly warning about the dangers to come in this seemingly new business practice, despite its being nothing but a reformulation of the good old idea of comparative advantages developed by Adam Smith and later by David Ricardo. Thus seen, offshoring poses as much threat to $21^{\text {st }}$ century workers as industrial revolution to farm laborers back in the $19^{\text {th }}$ century. Indeed, agricultural activities have not disappeared, but sharp entrepreneurs have often moved production far-off in the search for cheaper labor.

Although it seems reasonable to think of adjustment costs in the short term for workers and firms, one would expect the sectorial composition (rather than the quantity) of the economy's workforce to change in the future. This has been the story of capitalism since such a form of economic organization has existed. In the words of Blinder (2006), "the world as a whole cannot lose from increases in productivity" that are a natural result of trade and offshoring. Eventually, better paid and higher value-added jobs will open in the "relocating" economy due to economic scarcity.

\footnotetext{
1 Acknowledgments: I am grateful to Fundación BBVA for financial support through project grant 162/06. Also, I am indebted to Professors Raymond, Ricart, and Sala for their helpful comments, unrelenting encouragement, and inexhaustible patience.
} 
This is not to deny the possible short run layoffs or the implied dynamics the employers have to face when dealing with the decision to go abroad. But in the end these frictions should fade away as comparative advantages eventually turn out in increased social welfare, and the entrepreneurs finally succeed in making the most out of them (hopefully without much government interference). Hence, we should be thinking about offshoring as causing as much harm to an economy's labor market as international trade might also bring about. As we shall see here, offshoring and trade (intermediate trade, in particular) can be seen interchangeably.

Simply put, widespread fears on the subject usually revolve around the millions of jobs soon to be relocated from developed economies into developing ones, with a significant welfare cost in the former due to "employment destruction". However, these media reports as well as the surveys conducted by consulting firms have so far tended to overlook the brighter side of the story. Gains in terms of employment and productivity for local firms are not only possible, but probable. For instance, productivity gains could translate into price discounts and a boost in domestic demand, thus affecting employment positively. In fact, at a time when Japan is wavering at the crossroads of multiple futures, and doubts start assailing the population on prospects for a possible recovery, offshoring might well be the answer.

I therefore undertake the study of the Japanese economy for the period 1980-2005, using dynamic panel estimation for aggregate data. As we will see, the little evidence that has been collected for Japan refers only to the disaggregate level. Our empirical analysis then represents a robustness check on these studies and their conclusions, since it is undertaken at the industry level. To carry out such an endeavor I make use of the Japan Industrial Productivity database (JIP), which covers 108 industries or branches of activities. This is an exhaustive database with data on manufacturing industries, services industries, and other varied activities. I believe that such a complete database will help us understand the real extent of the phenomenon for Japan.

The empirical research presented here is divided in two, following Amiti and Wei (2006). First, I take a look at the demand side of the labor market and focus on the effects of offshoring on total employment, rather than on the relative employment among workers of different skills or their relative wages (as in Feenstra and Hanson, 1996a, 1996b, and 1999, for instance). We shall see that relative changes have attracted most of the interest so far, but due to the structure of the database it is only possible to study the direct effects upon employment. We shall see too that some of the later efforts are turning into this direction (Amiti and Wei, 2005 and 2006, and Cadarso et al., 2008). And second, I deal with the direct effects of offshoring on total factor productivity, while considering two possible ways of measuring the latter.

My goal is to provide some answers to the following questions: Can offshoring be seen as a source of new opportunities, both for workers and entrepreneurs? Are we to expect any improvement in the productivity of industries after offshoring takes place? To answer these questions we should first revisit some commonplace definitions. According to the OECD 2007 comprehensive summary, offshoring in the strict or narrow sense refers to business activities being relocated to subsidiaries abroad, while offshoring in the broad sense applies to relocation through third-party providers. These are also known as in-house offshoring and offshore outsourcing, respectively.

How best to proxy this phenomenon then, either in its narrow or broad form? It has been recently suggested that an extensive and rigorous way to do so is by looking at the trade data and the changes in intermediate goods and services imports (Feenstra and Hanson, 1996b, 1997, 1999). Specifically, it is the import content of intermediate trade (inputs) that best proxies 
offshoring and gives us a clue to understanding its economic implications. We shall see that for our industry level study this works just fine.

An outline of the paper is the following: In Section 2 I review a group of selected works, both at the aggregate and disaggregate level. Further, I point out the very few research works that have taken up the study of offshoring for Japan. Section 3 is devoted to analyzing the details of measuring offshoring properly, and to the econometric methodologies underlying our subsequent analysis. Section 4 goes over the data and provides an introductory statistical analysis. Later, and prior to estimation, I check on the suitability of our offshoring measures following a standard decomposition analysis. In the last part of this section I present the results of the set of estimated equations, regarding the employment and productivity effects of offshoring. Section 5 concludes the paper.

\section{The Story so Far}

Much has been said about offshoring in recent times, but much less has been produced in terms of sound and unambiguous empirical evidence. However, this relatively scarce literature has taken a drastic step forward since the mid 1990s.

Contributions to the subject of offshoring and its interplay with labor markets split into studies undertaken at different levels of aggregation. Highly aggregated (e.g., industry) works came in the first place, while the focus stayed somehow closer to the trade and productivity-related literature. ${ }^{2}$ Later on, with the labor market at the center of attention, several aggregate as well as disaggregate studies began to come to light. This implied some loss of homogeneity in the empirical definition of offshoring and the resulting little tangible consensus in the econometric results. In fact, nothing is as yet said about the real impact of offshoring on labor markets. Table A1 in the Appendix shows some of the evidence so far. A shortened chronological review follows.

\subsection{First Steps and Breakthrough}

The first contributions tried to explain the changes in the skill composition of the employed workforce or the underlying relative wages through variables other than productivity. Wage inequality among workers of different skills or shifts from non-skilled toward skilled labor could thus be explained by this "new" phenomenon. However, these studies found no decisive evidence of offshoring being a major driver of these relative changes. Berman et al. (1994), Krugman (1995), Lawrence et al. (1993), Leamer (1994), Siegel and Griliches (1992), and Slaughter $(1995,2000)$ present research along similar lines.

Feenstra and Hanson (1996b, 1997, 1999) produced evidence for the first time in favor of a shift towards skill-intensive activities within domestic industries due to offshoring. Their rationale was: if firms respond to import competition from low-wage countries by moving nonskill-intensive activities abroad, then trade has to shift employment toward skilled workers in the domestic economy. Therefore, it is the composition of trade, and the share of intermediate inputs in particular, that matters in the end for wages and employment. In their own words,

\footnotetext{
${ }^{2}$ See the references cited in the next paragraph.
} 
"trade in intermediate inputs can have an impact on wages and employment that is much greater than for trade in final consumer goods" (2001, p.1). As we shall see, offshoring can best be proxied using a measure that takes account of intermediate trade.

All these efforts described offshoring as a factor-biased technological change, in the sense that high-skill employment results improved after offshoring takes place, precisely because low-skill activities are more prone to go offshore due to potential labor cost gains. In this perspective, offshoring might just bring about an increase in the skill-intensity of production that comes with an increase in the wage rate for high-skill relative to low-skill labor. Feenstra and Hanson argue that if certain activities at the lower end in terms of skill intensity in the United States are offshored to Mexico, where they can be said to be at the upper end of the scale, then skill intensity goes up in both countries. Consequently, an increased demand for high-skill workers in both countries is accompanied by a rise in their relative wages, and offshoring becomes a form of factor-biased technological change.

The authors Feenstra and Hanson also contend that previous calculations might have underestimated the real extent of offshoring. In their 1996b paper, estimations suggest that offshoring can explain up to 31 percent of the increase in the nonproduction wage share during the 1980s for 450 United States manufacturing industries. Nonproduction employment is usually seen as a proxy for skilled labor whereas production employment most faithfully represents non-skilled labor. One must be very careful in defining the skill of workers since it might disguise some important information. The 1999 paper produced smaller numbers; there, offshoring accounted for 13 to 23 percent of the shift toward nonproduction labor, which is still a significant proportion.

\subsection{Aggregate Evidence}

Aggregate evidence, other than that previously mentioned, comprises a group of works inspired by Feenstra and Hanson's initial analysis. They all rely on their index or some of its variants to some extent, ${ }^{3}$ thus adding to the homogeneity and comparability of the results.

Functional as it may seem at first, aggregation might yet hide some empirical nuisances. In effect, it is to expect that within the same industry there can be firms that engage in offshoring more often than others. On another level, there are sectors which can offshore more than others. Conveniently, these phenomena are known as aggregation or sector bias. On another theoretical ground it is also possible to expect a bias in production factors since, as argued before, certain kind of labor (e.g. unskilled) is more prone to be relocated. A current debate exists as to whether sector (aggregation) or factor bias is more suitable when addressing offshoring and its effects on labor markets. ${ }^{4}$ Let us now go over some of the most significant works in a very brief manner.

\footnotetext{
35ee, for instance, Campa and Goldberg (1997), Hummels et al. (2001), and Egger and Egger (2003), for different versions of the same index. Horgos (2008) presents a comparative study of all these indices.

${ }^{4}$ For theoretical contributions on sector bias see especially Arndt $(1997,1998,1999)$. For factor bias see Feenstra and Hanson (1996a, 1996b, 1997, 1999). Krugman (2000) and Leamer (1998) present studies on relative factor prices adjustments due to either sector or factor bias.
} 
Egger and Egger (2003) use a panel of 20 Austrian manufacturing industries engaged in offshoring towards East Europe for the period 1990-1998. They find a change of relative employment by about 0.08 to 0.12 percent in favor of high-skilled workers. The fact that the low-skilled labor market is unionized, they argue, emphasizes the change in employment due to offshoring.

Strauss-Kahn (2004) draws on data from 50 French manufacturing industries during 19771993. She asserts that offshoring explains 11 to 15 percent of the drop in the share of unskilled workers in manufacturing employment during 1977-1985, and 25 percent of the decline during 1985-1993. It is theoretically more appropriate to rely on relative wage changes though, since it results from the cost-minimization problem of firms usually embedded in a (translog) cost function. The focus on relative employment rather than relative wages responds to particularly inflexible aspects of the labor market under study, as is the case of most continental European countries. As a conclusion, the author reasons that globalization has manifested itself through a significant decline in the within-industry share of unskilled workers for France.

Amiti and Wei (2005) conduct research that takes up the case of the United Kingdom with data from 69 manufacturing industries and 9 service industries during 1995-2001. They find no evidence of offshoring of materials and services having a negative effect on total employment, while estimating a conventional labor demand function. In their companion paper, Amiti and Wei (2006) corroborate this for the United States economy using 96 industries in 1992-2000. However, when the economy is decomposed into 450 industries, a negative effect on employment is detected. Further, they find a positive effect of offshoring on productivity, ranging from 11 to 13 percent of productivity growth being accounted for by services offshoring and from 3 to 6 percent by materials offshoring. Two points are worth stressing about both works by these authors: first, their methodology detours from the translog cost estimation employed up to those days, and second, they consider services offshoring empirically for the first time.

Egger and Egger (2005) again dig up the case for Austria, using a panel of 21 industries in the 1990s. And again they find a positive effect of offshoring towards high-skill workers. This time the numbers are much larger though ( 9 to 10 percent), because of the important role of intersectoral spillovers which are now being considered. These spillover effects may be of two kinds. First, offshoring practices by one industry which might impact on another due to inputoutput linkages, and second, national labor flows across industries. The authors can therefore avoid a substantial underestimation of the labor market effects of offshoring.

Hijzen et al. (2005) analyze 50 British manufacturing industries during 1982-1996, and discover a strong negative impact on the demand for unskilled labor. They are able to use information directly linked to occupational classifications, as opposed to the standard division between production and nonproduction workers, which corresponds to the basic non-skilled/skilled classification.

Canals (2006) uses data in a sample of 27 United States industries (18 manufactures, and 9 services), over the period 1980-1999, and finds out that offshoring explains 28 percent of the observed wage change. She carries out an accounting decomposition which is analogous to the growth decomposition within the productivity literature. The wage gap can then be explained by shifts in offshoring, shifts in biased technological change other than offshoring, and total technological change. 
Ekholm and Hakkala (2006) present evidence for 20 industries from Sweden in the period 19952000. Their results hint at an important contribution of offshoring in the shift of relative labor demand away from the group of workers with upper secondary education. This is only significant when considering offshoring to low-income countries but not to high-income ones.

Cadarso et al. (2008) employ data from 93 Spanish industries for the period 1993-2003. They suggest that the effect of offshoring varies depending on the industry's characteristics and the country of origin. Their estimation implies a negative effect on labor which turns out significant for medium and high-tech industries (when offshoring comes from Central and Eastern European countries) while it is non-significant for other countries and low-tech sectors.

\subsection{Disaggregate Evidence}

Disaggregate evidence allowed researchers to get rid of the aggregation-sector bias and thus provide a clearer picture of the phenomenon. While it might indeed prove helpful, allegedly allowing a more in-depth analysis, disaggregate evidence can at the same time bring some loss of homogeneity in the definition of offshoring and, therefore, the impossibility of carrying out direct comparisons. I now examine the results offered by these contributions but avoid going into details of what exact definition was used in each case and how it differs from others. This would otherwise imply an unending venture.

Egger et al. (2003) use data on Austrian male workers (around 30,000) over the period 19882001. They offer an approach for studying the transition probabilities of employment into other sectors, accounting for intermediate steps into the pool of unemployed, or out of the labor force. The results prove that international factors are important for labor market turnover, especially for what they call industries with a comparative disadvantage (net importing industries). They remark that increases in imports, terms of trade and, more importantly, the share of offshoring in total trade, negatively affect the probability of staying in or changing into the manufacturing sector.

Girma and Görg (2004) study 14,000-19,000 establishments in the United Kingdom manufacturing sector, for the period 1980-1992. The authors take account of the decision to go offshore and the effect of such a decision on the establishments' productivity. They find that there is strong persistence in the offshoring decision and that foreign establishments offshore more than domestic ones. Also, they find that offshoring has significant positive effects on productivity.

Criscuolo and Leaver (2005) use establishment data for both the manufacturing and services sectors in the United Kingdom (35,000 plants approximately) during a short span, 2000-2003. They determine that a 10 percentage point increase in (services) offshoring intensity is associated with a 0.37 percentage point increase in total factor productivity. This effect comes mainly from firms that are domestic and non-globally engaged.

Geishecker and Görg (2005) carry out the study for the German manufacturing sector including 1612 individuals during the period 1991-2000. They come to the conclusion that only lowskilled workers employed in low-skill-intensive industries experience reductions in their real wages following fragmentation activity in those industries. The wage elasticity indicates that a one percentage point increase in fragmentation intensity (offshoring) leads to a reduction in average wages by 3.6 percent. On the contrary, high-skilled workers in the high-skill-intensive industries might expect a rise of 2.7 percent in average wages due to a one-percentage point increase in fragmentation. 
Görg and Hanley (2005) employ data on 650 establishments for the Irish Electronics sector in the period 1990-1995. They find that a fall of 0.27 percent in employment can be explained by a 1 percent increase of offshoring. They also report significant individual effects of materials and services offshoring, with stronger effects from the former. Respectively, elasticities are -0.20 and -0.15 .

Crinò (2007) presents highly disaggregated data on 58 white-collar occupations in 144 United States industries for the period 1997-2002. He shows that services offshoring is skill-biased because, contrary to common perception, it raises employment among high-skilled occupations and lowers employment among medium- and low-skilled ones.

Hakkala et al. (2007) use data on 15,000 Swedish firms during 1990-2002. Their results reveal that there exists no clear difference between foreign and domestic firms, or between multinational and non-multinational firms, as regards wage elasticities.

\subsection{What's with Japan?}

Japan's offshoring remains in the shadows, as is the case for much of Japan's puzzling performance in the 1990s. The following are some papers that have only recently seen the light of day, and deserve to be looked at with a keen eye.

To my knowledge, the first step towards an understanding of the dealings of Japan with offshoring and its effects on the labor market is the research by Head and Ries (2002). The authors present evidence of 1070 multinational firms in the manufacturing sector for 19711989, that supports the direct relation between multinational activity and domestic skill upgrading. Results in a set of different specifications and samples show that changes in overseas employment shares can explain a 0.9 percentage point increase of the roughly 10 percentage point increase in the share of non-production workers. On other accounts, they show that increasing domestic skill intensity dwindles as investment shifts eventually towards higher-income countries.

Another contribution at the firm level is Tomiura (2005), who considers a survey from 1998 of 118,300 firms in all manufacturing industries. Surprisingly, nearly 98 percent did not offshore any of their production overseas. The extensive nature of the sample employed in this study bears some limitations though, as made explicit by the author. First, offshoring of services is not covered, and second, only manufacturing firms are considered. The interest relies then on the determinants of offshoring for the individual firm, among which we find several firm-level characteristics. The endowment of human skills and the experience with FDI are found to be of high importance. Along the same lines, more productive firms and those whose products are more labor-intensive display a more extensive offshoring intensity.

A recent paper by Hijzen et al. (2006) focuses on the productivity side, while covering 12,564 manufacturing firms in the years 1994-2000. Indeed, positive productivity effects have been consistently exposed in most of the works that undertook that task, as previously reviewed. ${ }^{5} \mathrm{~A}$

\footnotetext{
${ }^{5}$ The story of employment is somehow left out of works concerning productivity issues. However, a caveat is in order. Employment creation (if any) in the shortest term as a result of productivity gains is usually understood as taking place in a different sector or industry. Certainly, when firms become more productive they can produce with less (not more), be that capital or labor, while workers are faced with the real threat of unemployment. In the longer term, though, offshoring firms are faced with the scale effect. That is, offshoring-related productivity increases can make firms more efficient and competitive after a while, increasing the demand for their output and exerting a positive effect on labor. See Olsen (2006) for a complete account of the offshoring and productivity story.
} 
one percent increase in offshoring intensity, these authors assert, would raise productivity growth by 0.17 percent. Further, for the average offshoring firm this would imply a 1.8 percent increase in annual productivity growth. They also find that the potential extent for productivity improvements depends negatively on the initial level of productivity of the firm. Thus, they suggest that "offshoring may be an effective channel in restoring the competitiveness of less productive firms" (p. 5). And also, "that specializing in skill-intensive production stages through offshoring generates higher growth in productivity due to larger learning-by-doing effects" (p. 7). On the same grounds, they find multinationals to be more important offshorers than purely domestic firms.

Ito et al. (2007) analyze a survey from 2006, including more than 5,000 large-sized firms from all manufacturing industries. Their main results indicate that offshoring is more present now than five years ago: sampled firms engaged in offshoring went from 15 percent in 2001 to 20 percent in 2006. Moreover, production-related tasks take most of the offshoring pie, while services offshoring is still of a rather narrow scope. Also according to these data, offshoring for Japanese firms is mainly restricted to own affiliates within East Asia.

We can see that the evidence on Japan, at least all that I am aware of, consists of firm-level studies displaying the expected qualitative conclusions that abound elsewhere in the literature. Namely, that a factor-biased technological change might occur when offshoring takes place, favoring high-skilled workers domestically (Head and Ries, 2002), and that productivity gains are surely to be expected as a result of offshoring (Hijzen et al., 2006). Tomiura's work, however, raises important questions around the subject and its significance for the Japanese economy. In spite of the latter, I believe it proper to set out the case at a more aggregate level based on several reasons. First, it has never been undertaken; second, the estimates with highly aggregated data remain somehow comparable among the different studies due to the homogeneity of the indices employed; and third, it might prove a robustness check on the previous Japanese evidence. Two broad differences set the current research aside from these works. The one is that I take the whole economy and not just one sector; the other is that I include services offshoring in the analysis.

\section{Measurement and Estimation Issues}

How to define offshoring when it comes to empirics? In other words, how to proxy its theoretical definition quantitatively? Roughly speaking, offshoring can be measured either directly or indirectly. Nevertheless, the lack of reliable direct data should make us consider indirect measures to a greater extent. ${ }^{6}$ The indices on intermediate trade that I discuss below have so far proved to be reliable proxies.

\footnotetext{
${ }^{6}$ Kirkegaard (2007) breaks down the different sources to measure offshoring into three empirical hierarchies. The lowest tier encompasses all the estimations and projections by consulting companies (Forrester Research, 2004, and McKinsey, 2003, for instance). Second-class data belong to the estimates produced by the press, mostly resorting to public and verifiable sources. And finally, the indirect measures we discuss here place at the top of this ranking.
} 


\subsection{Indirect Indicators}

A benchmark contribution is Feenstra and Hanson (1996a, 1996b, 1997, 1999). There, offshoring is defined as the share of imported intermediate inputs in the total purchase of nonenergy inputs. They combine United States import data from the four-digit SIC (Standard Industrial Classification) with data on material purchases from the Census of Manufactures. The census data crisscross the trade between industries of the same level and provides the base for estimating the share of intermediate inputs in every industry. For a given industry $i$ at time $t$, multiplying the shares of input purchases from each supplier industry times the ratio of imports to total consumption in the supplier industry, and then adding over, turns out in their offshoring intensity measure. More formally, this can be written as follows:

$$
O S_{i t}=\sum_{j}\left(\frac{I_{j t}}{Q_{t}}\right)^{i}\left(\frac{\Pi_{j t}}{D_{j t}}\right)
$$

where is purchases of inputs $J$ vy muusuy $\iota, \mathcal{v}$ is ivia miputs (excluding energy) used by $i$, $\pi_{j}$ is total imports of goods $j$, and $D_{j}$ their domestic demands. This formula provides an index of the offshoring intensity at the industry level. It estimates the import content of intermediate trade of industries which, in turn, proxies their offshoring intensities. Specifically, the first term in (1) stems from the census data (or Input-Output tables), while the second term, which is an economy-wide import share, is obtained from the trade data.

Conveniently, this expression serves as a measure for both the traditional offshoring of materials and the more fashionable offshoring of services. ${ }^{7}$ Besides, it is useful to split offshoring into its narrow and broad measures. The narrow measure restricts to imported intermediate inputs from the same two-digit industry whereas the broad measure includes all other industries as well. In particular, when $i=j$ we have that the equation in (1) becomes the narrow measure. Also the difference between the broad and narrow measures, which represents all imported intermediate inputs from outside the two-digit purchasing industry, stands as an alternative when it comes to capturing the true nature of offshoring. Other indices used in the literature are: the imported inputs in total output ratio (see for instance Egger and Egger, 2003), or the vertical specialization index, which accounts for the imported inputs content of exports (see here Campa and Goldberg, 1997, and Hummels et al., 2001).

A common drawback to all measures relying on import shares is that offshoring does not necessarily imply an increase of imports, and vice versa. If a local exporting firm decides to move part of its production abroad and continues exporting it from a foreign country this would not translate into a drop in imports to the parent firm. Rather, it would represent a fall of its exports. Likewise, a rise in a country's imports due to more favorable terms of trade should not be linked in any fashion to an expansion of offshoring from local firms. Another disadvantage for this particular index is that the second term in (1), the import penetration of inputs, is usually taken as equal for every industry.

The rationale for using these kind of indices should be clear: importing trade stands for an important amount of intra- and inter-firm trade nowadays, from which offshoring could be proxied. Upon availability of imported intermediate inputs data, Equation (1) can readily be reduced to:

\footnotetext{
${ }^{7}$ Amiti and Wei $(2005,2006)$ elaborate on this index as to account for both types of offshoring, materials and services, at the industry level.
} 


$$
O S_{i t}^{\prime}=\sum_{j}\left(\frac{\eta_{j t}}{Q_{t}}\right)^{i}
$$

where $O S_{i t}^{\prime}$ is the offshoring intensity index expressed directly as a ratio in terms of total purchases of imported intermediate nonenergy inputs. The numerator in (1'), $\eta$, represents the imported intermediate inputs which correspond to the diagonal element of import-use matrices. Most of times it is not possible to use such simple expressions as (1') in an extensive time period. Input-Output tables are periodically published around every five years and remain one of the few direct sources of $\eta$; this is why it is usually estimated through trade data, as in (1). Therefore, the statistical and econometric analysis of the following sections relies on the broad measure drawn from equation (1) above.

\subsection{Estimation Methodology: Employment}

Departing from the neoclassical model of exogenous growth (Arrow et al., 1961), the linear homogeneous production function for the industry with two inputs (labor, $L$, and capital, $K$ ) is given by:

$$
Y_{i}=A(t)\left[(1-\alpha) K_{i}^{\rho}+\alpha L_{i}^{\rho}\right]^{1 / \rho}
$$

This is the constant elasticity of substitution technology production function (CES) which, under perfect competition, implies that the distribution parameters $\alpha$ and $1-\alpha$ are equal to the input share parameters. We also have that $0<\alpha,(1-\alpha)<1$ (due to positive and diminishing marginal products of each input) and $-\infty<\rho<1$ (which is the degree of substitutability of the inputs). Moreover, $\mathrm{A}(t)$ is the time-dependent Hicks-neutral technological parameter; "neutral" meaning that it does not affect the optimal choice of inputs by industries. Further assuming the case of unit elasticity of substitution $(\rho=0)$ and constant returns to scale, ${ }^{8}$ equation (2) becomes the usual Cobb-Douglas specification: ${ }^{9}$

$$
Y_{i}=A(t) K_{i}^{(1-\alpha)} L_{i}^{\alpha}
$$

\footnotetext{
${ }^{8}$ The elasticity of substitution in production is a measure of how easy it is to shift between factor inputs. A generalization of the power in equation (2) would be: $\frac{\tau}{\rho}=\frac{\sigma}{(\sigma-1)}$, with $\sigma$ the elasticity of substitution and $\tau$ the degree of homogeneity. Increasing, decreasing, and constant returns come with $\tau>1, \tau<1, \tau=1$ Constant unit elasticity and constant returns therefore imply $\sigma=\tau=1$.

${ }^{9}$ Which is a special case of the CES neoclassical specification above. Other particular yet extreme cases occur when $p=1$ and $\rho=-\infty$, the perfect substitution and no substitution (Leontief function) cases respectively. Barro and Sala i Martin (2003) define a production function as neoclassical whenever the three following conditions are met: (1) constant returns to scale, (2) positive and diminishing marginal products to inputs, and (3) the Inada conditions. More formally: (1) $F(\lambda K, \lambda L, A)=\lambda F(K, L, A), \quad$ for $\quad$ all $\quad \lambda>0$, (2) $\quad \frac{\partial F}{\partial K}>0, \frac{\partial^{2} F}{\partial K^{2}}<0 \quad$ and, (3) $\frac{\partial F}{\partial L}>0, \frac{\partial^{2} F}{\partial L^{2}}<0 \lim _{K \rightarrow 0} \frac{\partial F}{\partial K}=\lim _{L \rightarrow 0} \frac{\partial F}{\partial L}=\infty$ and $\lim _{K \rightarrow \infty} \frac{\partial F}{\partial K}=\lim _{L \rightarrow \infty} \frac{\partial F}{\partial L}=0$.
} 
Accepting that the whole economy can be represented as a single profit-maximizing firm, from our knowledge of the production function we can derive the cost function, which reduces to:

$$
C(w, r, Y)=\phi r^{1-\alpha} w^{\alpha} Y
$$

$\phi$ being a constant, $r$ and $w$ the factor prices (the interest rate and wages, for instance), and $Y$ real output. As we can see, the cost function and the production function are different sides of the same coin. With exogenous input prices, the production function and the cost function contain virtually the same information. Generalizing, a multifactor Cobb-Douglas cost function can be written as $C=Y \prod_{i} Z_{j}^{\alpha i}, \Sigma \alpha_{i}=1$. Notice that the cost function, due to constant returns to scale, is always linear in $Y$.

It must be remembered at this point that, particularly in former efforts, it was most appealing to specify a translog cost and production functions. ${ }^{10}$ This provided a more flexible framework as regards cross elasticities that led to the estimation of a factor-share equation. We should keep in mind though, that the original debate was all about explaining the wage gap (e.g., the wage skill premium) or the shifts in relative employment of both non-skilled and skilled labor, due essentially to some form of technological change (see Berman et al., 1994, and Feenstra and Hanson, 1996b, most representatively). Some of the current efforts, however, try to disentangle a more direct incidence of offshoring on total employment as in, for example, Amiti and Wei $(2005,2006)$ or Cadarso et al. (2008), who implicitly assume a Cobb-Douglas technology. In this way we can say that cost minimization, which entails the optimal demand for inputs given a certain level of output, is characterized by the conditional demand for labor augmented by other factor prices.

Following Hamermesh (1993), minimizing total costs in (4) subject to (3) and using Shephard's lemma (Hicks, 1939; Samuelson, 1947; Shephard, 1953) yields the factor demand functions for $K$ and $L$. For the labor factor we have:

$$
L_{i}=\Gamma\left(w_{i}, p_{i}, Y_{i}\right)
$$

where the demand for labor depends on wages $w_{i}$, other factor prices $\rho_{i}$, and output $Y_{i}$. Among input prices other than $r$, we can identify, following Amiti and Wei $(2005,2006)$, the price of foreign labor services. These pose as a substitute for domestic labor and enter the labor equation:

$$
L_{i}=\Gamma\left(w_{i}, p_{i}^{\prime}, p_{i}^{o s}, Y_{i}\right)
$$

Since data on $\rho_{i}^{o s}$ are often hard to get, (Amiti and Wei) propose the offshoring intensity indices as an inverse proxy of the price of these imported intermediate inputs.

$$
L_{i}=\Gamma\left(w_{i}, p_{i}^{\prime}, Y_{i}, O S S_{i}, O S M_{i}\right) \mid A\left(O S S_{i}, O S M_{i}\right)
$$

\footnotetext{
${ }^{10}$ See Appendix B.
} 
where $O S S_{i}$ and $O S M_{i}$ are the services and manufacturing offshoring indices, and $A$ is the technology shifter dependent on offshoring. Here Amiti and Wei $(2005,2006)$ identify three channels through which offshoring comes to shake the labor demand. First, a possible substitution effect between labor and prices of imported inputs (services or materials); a drop in the latter or, equivalently, an increase in the offshoring indices, would lead to a fall in the demand for labor. Second, a possible short run productivity effect of offshoring to impact negatively on employment. And third, the scale effect which might positively affect labor, provided firms are more efficient and competitive in the longer term due to previous productivity gains.

Adding the subscripts to the previous formulation, a widely used equation in the recent literature is given by:

$$
\begin{aligned}
\ln L_{i t}= & \beta_{o}+\beta_{1} \ln L_{i t-1}+\beta_{2} \text { OSS }_{i t}+\beta_{3} \text { OSM }_{i t}+\beta_{4} \ln w_{i t}+\beta_{5} \ln p_{i t}^{\prime}+\beta_{6} \ln Y_{i t} \\
& +\beta_{7} Z_{i t}+\delta_{i} d_{i}+\delta_{t} d_{t}
\end{aligned}
$$

Labor is regressed on its lagged value and a set of variables which include, respectively: the services and materials offshoring intensity indices OSS and OSM, real wages $w$, other factor prices $\rho^{\prime}$ (such as $r$ ), the volume of output $Y$, and a vector $Z$ of other control variables among which we can consider the capital stock or some measure of R\&D investment. Industry and years fixed effects also enter the equation through the dummy variables, $d_{i}$ and $d_{t}$. Error terms are omitted throughout for the benefit of exposition.

Now taking account of the scale effect, substituting the price of output for the quantity of output yields the unconditional version of (7):

$$
\begin{aligned}
\ln L_{i t}= & \gamma_{o}+\gamma_{1} \ln L_{i t-1}+\gamma_{2} \text { OSS }_{i t}+\gamma_{3} \text { OSM }_{i t}+\gamma_{4} \ln w_{i t}+\gamma_{5} \ln p_{i t}^{\prime}+\gamma_{6} \ln p_{i t}^{Y} \\
& +\gamma_{7} Z_{i t}+\delta_{i}^{\prime} d_{i}+\delta_{t}^{\prime} d_{t}
\end{aligned}
$$

On the expected signs of the coefficients we have that $\beta_{4}, \gamma_{4}<0, \beta_{5}, \gamma_{5}>0$ (if inputs are gross substitutes), $\beta_{6}, \gamma_{6}>0, \beta_{2}, \beta_{3}<0$ while $\gamma_{2}$ and $\gamma_{3}$ are inconclusive, since it is not clear whether the scale effects are large enough to outweigh the substitution and productivity effects. As stated before, the output may be increased in response to offshoring-related productivity gains.

A couple of remarks by Amiti and Wei (2006) need be recapped. First, relying on the assumption of perfect mobility of labor across industries, we can state that wages are exogenously determined. If that is not the case though, then wages are endogenous. Provided that these potential rents are unchanged over time, we can assume that they would be absorbed by the industry fixed effects $\left(\delta_{i}\right.$ and $\left.\delta_{t}^{\prime}\right)$, so the results would still be unbiased. And second, the price for other inputs (such as imported inputs and the rental on capital) are considered as a function of time, so they are captured by the time fixed effects $\left(\delta_{t}\right.$ and $\left.\delta_{t}^{\prime}\right)$.

A serious problem with both specifications in (8) and (8') is the strong endogeneity of the output variable $Y$. Even though most empirical work employs both expressions on a regular basis, they remain of dubious interpretation as the measured coefficients on the real wages 
variables represent partial elasticities and not total elasticities (Webster, 2003). ${ }^{11}$ For this reason, the exogenously determined capital stock variable is made explicit in our final estimating equation with no output variable (whether it is the volume or value version):

$$
\ln L_{i t}=\theta_{o}+\theta_{1} \ln L_{i t-1}+\theta_{2} O S S_{i t}+\theta_{3} O S M_{i t}+\theta_{4} \ln w_{i t}+\theta_{5} \ln K_{i t}+\delta_{i}^{*} d_{i}+\delta_{t}^{*} d_{t} \text { 9) }
$$

Notwithstanding the previous assumptions in the last two paragraphs, the estimation of equations (8), (8'), and (9) in their static or dynamic forms still entails potential endogeneity problems due to the offshoring variables. A potential bias in OLS estimates is expected and should lead us to consider the implementation of instrumental variables techniques.

\subsection{Estimation Methodology: Productivity}

Productivity can be measured in multiple ways. Fundamentally, it can be either measured as a ratio of a volume measure of output to a volume measure of input, or as a measure depending on all types of inputs. In this way it is possible to distinguish between labor and capital productivity on the one hand (a single-factor measure), and total factor productivity (TFP) on the other (that is, a multi-factor measure). Different measures of outputs and inputs and, thus, of productivity, reflect different representations of the same production process in a particular industry (Zheng, 2005). We are interested in calculating two of these widely used measures of the TFP for Japan and then estimating the direct effect of offshoring. This is the usual twostage estimation methodology.

First we have a generalization of the gross value added (or net output) representation of the production function. Gross value added is obtained by deducting intermediate consumption from gross output, and includes wages, consumption of fixed capital, pre-tax profits, and indirect taxes and subsidies. Such an output measure can be represented through the two primary inputs:

$$
Y_{i}^{V}=F\left(K_{i}, L_{i}, t\right)=A(t) f\left(K_{i}, L_{i}\right)
$$

where gross real value added $Y_{i}^{V}$ depends on labor $L$, capital $K$, and the Hicks-neutral and time-dependent technological parameter $A(t)$.

Additionally, we can consider the gross output-based measure, which is a representation of the production function augmented by materials and services inputs:

$$
Y_{i}^{G}=G\left(K_{i}, L_{i}, M_{i}, S_{i}, t\right)=A^{\prime}(t) g\left(K_{i}, L_{i}, M_{i}, S_{i}\right)
$$

where gross real output $Y_{i}^{G}$ depends on labor $L$, capital $K$, materials inputs $M$, services inputs $S$, and the neutral technological shifter $A(t)$.

\footnotetext{
11Webster (2003) continues: "A total elasticity includes the full effects on employment, once the effects on intermediate variables such as output have been worked through. Partial elasticities are the effects if one or more of these intermediate variables are artificially held constant. Partial elasticities are artificial 'thought experiments', as in real life it is not possible to control most variables" (p. 135, footnote 5).
} 
Differentiating both expressions with respect to time and considering constant returns to scale we get, through Euler's theorem, the contributions of the growth in inputs to the TFP growth:

$$
\begin{gathered}
\dot{Y}_{i}^{V}=\zeta_{K} \dot{K}+\zeta_{L} \dot{L}+\tau_{V} \\
\dot{Y}_{i}^{G}=\eta_{K} \dot{K}+\eta_{L} \dot{L}+\eta_{M} \dot{M}+\eta_{S} \dot{S}+\tau_{G}
\end{gathered}
$$

where $\zeta_{Z}=\frac{\partial F}{\partial Z} \frac{Z}{F}$ and $\eta_{Z}=\frac{\partial G}{\partial Z} \frac{Z}{G}$ (with inputs Z) are the elasticities of output to the different inputs, $\tau_{V}=\frac{\partial \ln F}{\partial t}=\dot{A}$ and $\tau_{G}=\frac{\partial \ln G}{\partial t}=\dot{A}^{\prime}$ correspond to the changes in the Hicks-neutral residuals, and $\dot{X}=\frac{d \ln X}{d t}$ is the growth rate for any variable in (12) and (13). Under the simplifying assumptions of constant returns and perfect competition in the market of both output and inputs, these equations become:

$$
\begin{gathered}
\tau_{V}=\dot{Y}_{i}^{V}-s_{K} \dot{K}-s_{L} \dot{L} \\
\tau_{G}=\dot{Y}_{i}^{G}-s_{K}^{\prime} \dot{K}-s_{L}^{\prime} \dot{L}-s_{M}^{\prime} \dot{M}-s_{S}^{\prime} \dot{S}
\end{gathered}
$$

Notice that under both these assumptions Solow's residual equals TFP. Because of the competitive equilibrium assumption in particular, equations (14) and (15) also imply the equivalence between factor income shares and output elasticities. That is, $s_{z} \equiv \frac{p_{z}{ }^{z}}{p_{v} Y^{v}}=\zeta_{z}$ and $s_{Z}^{\prime} \equiv \frac{p_{z^{Z}}}{p_{G} Y^{G}}=\eta_{Z}$, with $p_{Z}$ the price or return to inputs, and $p_{V}$ and $p_{G}$ the prices of real valueadded and real gross product respectively. Each input is thus paid its marginal product, and due to constant returns to scale, the factor shares add up to 1: $\Sigma s_{Z}=1$ and $\Sigma s_{Z}^{\prime}=1$.

The analysis stands aside from the debate over whether value added or gross output are more appropriate in measuring output and productivity. ${ }^{12}$ Estimating both Cobb-Douglas production functions in (10) and (11) will deliver, through the assumptions embedded in (12) and (13), both productivity measures in (14) and (15). These are two common measures of productivity growth widely used in the literature. ${ }^{13}$

Once our series $\tau_{v}$ and $\tau_{G}$ are constructed, we are able to estimate the effects of offshoring directly. We should remember, though, that since the TFP growth measures are estimated

\footnotetext{
${ }^{12}$ Zheng (2005) states that, at the industry level, the value-added productivity measure might be more sensitive to offshoring than its gross output counterpart. See the example therein provided (pp. 16-17).

${ }^{13}$ See Griliches (1996) and Hulten (2001) for a bibliographical survey and Zheng (2005) for a review of the main indices (which are not considered here) that can be derived from the production function using a nonparametric approach. According to this author, these indices can account for the technological change of a more general nature (e.g. non-neutral Hicks). For instance, in a production function like $Y=H(A K, L)$, the residual affects capital but not labor; in $Y=H(K, A L)$ it affects labor but not capital. These two cases can be described as Hicks-biased, and would account for a rotation of the isoquant curves (instead of a shift, which is our case). This is in line with Feenstra and Hanson's argument of a skill-biased technological change. For our purposes here, the derivation of our measures in equations (14) and (15) through the parametric estimation of the production functions in (10) and (11) will suffice.
} 
relying on the real values of inputs and output, the cost-saving motive usually attached to offshoring is therefore left out of the analysis. The second stage estimating equations are simply:

$$
\begin{gathered}
\tau_{V i t}=\Omega\left(O S S_{i t}, O S M_{i t}\right) \\
\tau_{G i t}=\Lambda\left(O S S_{i t}, O S M_{i t}\right)
\end{gathered}
$$

We expect the coefficients associated to both OSS and OSM to be positive in both specifications. As with employment, potential endogeneity of offshoring is also present in both these equations. Either more productive industries self select into offshoring or, conversely, industries that expect a fall in productivity growth increase their levels of offshoring in the hope of increasing their productivity (Amiti and Wei, 2006). Here again, instrumental variables should be considered.

This simple methodology ${ }^{14}$ is in the spirit of Hayashi and Prescott (2002) benchmark contribution to the understanding of Japan's poor TFP performance in the 1990s. In their own words, treating TFP as exogenous (as I do here) would account well for the Japanese lost decade of growth.

\section{Empirical Analysis}

\subsection{Data}

The JIP Database $(2006,2008)$ provides a comprehensive source for a wide set of variables through a relatively long time period and for the whole Japanese economy. It has been compiled in a joint project by the RIETI (Research Institute of Economy, Trade \& Industry), Hitotsubashi University, and the Economic and Social Research Institute (ESRI), all based in Japan. Two versions have been released to date, comprising annual data for the period 19702005 and covering a total of 108 activities from both the manufacturing and services sectors. Strictly speaking, this classification does not correspond exactly to the industry classification usually found elsewhere (e.g., ISIC, rev. 3, or the EU KLEMS project), but does stand as a faithful approximation. ${ }^{15}$

The database includes data on 54 manufacturing activities, 42 services activities, plus 12 activities which belong into other varying sectors of the economy (the primary sector plus energy). Table A2 in the appendix lists all the activities that make up the JIP database, separated into three sectors: manufacturing, services, and other.

Due to a possible aggregation bias (which underlies the whole empirical analysis), the measurement errors of the offshoring index, and the potential endogeneity of this variable in

\footnotetext{
${ }^{14}$ Hijzen et al. (2006) also adopt this two-step estimation procedure for Japan, although at the firm level. Another reference of interest is the methodological review by Van Beveren (2007), which goes over the different alternatives when classical hypotheses do not hold. See also Kee (2004) in this regard.

15For a detailed description about this database, including the concordance with other industry classifications, see Fukao et al. (2007).
} 
the econometric analysis, it is important to note that any conclusions should be interpreted with caution. To estimate the offshoring index I employ the definition in (1) above, resorting exclusively to the JIP Database. This is a positive feature since the Feenstra and Hanson-type index necessarily takes data from intermediate inputs and trade, which usually stem from different sources.

As for our index on materials offshoring we have from (1) that this is the import content in all materials inputs. Hence, the first term is the input purchases of material $j$ by industry $i$ at time $t$, as a share of that industry's total use of materials inputs. The second term is a global measure of the import penetration of the referred input $j$ which, even though is time-varying, it remains fixed across industries or branches of activities. This implies the assumption that all industries carry out the importing of these materials with the same intensity. The same reasoning applies to the construction of the services offshoring index. ${ }^{16}$

\subsection{Descriptive Statistics}

\subsubsection{Materials and Services Offshoring}

It is time now to shed some light on our particular picture. Figure A1 and Table A3 show the evolution of materials and services offshoring according to formula (1), weighted by industry value added. Tables A4 and A5 present a breakdown of manufacturing and services activities. ${ }^{17}$ These offshoring indices do not account for the region of origin of the imported intermediate inputs, since these data were unavailable. Three things are however worth commenting on these tables.

First, materials offshoring, proxied by its import content in the industries' total use of materials, is expectedly more predominant. Second, the annual rate of growth of services offshoring is, on average, surprisingly smaller than that of materials in the whole sample period. Due to an everincreasing globalized world where technologies abound and change fast for the better, one should have expected the opposite to be true, since services offshoring certainly entails a higher value-added process. In particular, this is what happened in the period before the 'bubble crisis' and the 'lost decade', when the rates of growth were approximately equal. Finally, it is worth noting the slowdown in both indices' growth rates, but especially in services offshoring, during the 'lost decade' and up until the present. In any case, the average annual growth rate for services offshoring was in fact negative during that period. A possible explanation, which adds to that of the domestic crisis, is the loss of appeal for services offshoring to be hosted in neighboring Asian countries. ${ }^{18}$ This might be due to a relative loss of competitiveness that

\footnotetext{
${ }^{16}$ In order to come up with the offshoring indices I used the Input-Output tables in section 1.4 of JIP, and the final demand tables in section 1.7, both at constant prices (2000). The import figures had to be linearly interpolated; only years 1980, 1985, 1990, 1995, and 2000 were available. As a result, the empirical analysis below starts in 1980.

${ }^{17}$ The average annual growth rates in these tables are calculated using a compound annual growth rate index (CAGR). This can be expressed as follows:

CAGR $=\left(\frac{\text { ending value }}{\text { beginning value }}\right)^{\left(\frac{1}{\text { \#of years }}\right)}-1$.

18Ito et al. (2007) stress the preference for large-sized Japanese firms to have their relocation processes channeled into the region while following an in-house (captive) strategy.
} 
comes with the catch-up process in those fast-growing countries. Also, the gap in the TFP growth between manufacturing and services industries might account for the difference in the evolution of the different kinds of offshoring. Naturally, materials offshoring is more related to manufacturing industries whereas services offshoring is more often found in services industries. For some authors it was the TFP of the latter industries which suffered more, especially during the 1990s (see Ahearne and Shinada, 2005, and Caballero et al., 2008). Others however state the opposite, that the downturn in the TFP growth was more serious in manufacturing (see for example Miyagawa, 2003, and Fukao et al., 2004).

There is really no significant difference between the numbers provided in Tables A4 and A5 and those shown in A3, yet the separation in types of activities allows us to go even further. The average growth rate of offshoring intensity, for both materials and services, appears as slightly higher for services activities for the whole period. Reasonably enough, one would expect the services sector to invest more in new technologies and be more aware of the possibilities that offshoring represents as a source for cheaper imported inputs.

\subsubsection{Employment and Productivity}

Table A6 depicts the top ten offshorers in terms of their growth rate for the entire sample (both of materials and services) and the associated growth rates of employment. Almost for every top-ten industry engaged in materials offshoring we observe negative employment rates. Further, these industries are among the least successful in employment creation and, only with a few exceptions, rank at the bottom ( $60^{\text {th }}$ place and up). On the other hand, services offshoring seems to be much friendlier towards employment creation, as almost every industry in the top ten displays positive growth rates (all ranking in the first 50). ${ }^{19}$ However, it should be noted the extremely high rates of employment creation in highly dynamic services industries, to wit: Video \& sound (11.16 average annual percent growth) and Information and Internet services (9.83 percent).

On the productivity side there are also some features worth remarking. Yet noticeable at first glance from figure A2, we must mention the rather pessimistic performance in the average annual growth rates for the TFP during the 1990s. According to our data, these take the following values: 1.00 percent (1980 to 1990) and -0.77 percent (1991 to 2005) for the valueadded measure in equation (14), and 0.39 percent (for years 1980 to 1990) and -1.12 percent (1991 to 2005) for the TFP output-based measure in equation (15). In spite of the limitations of our simple methodology, and the fact that our analysis only looks for the effects of offshoring on productivity (and employment), others studies have produced similar unpromising results. ${ }^{20}$

Even though this study does not attempt to go into the details of the causes that brought the lost decade into existence, some observations are in order. The "zombie firms" hypothesis has been put forward on occasions, mainly to explain the important decline in the TFP as measured by many different estimates. Seemingly, unproductive firms ("the zombies") keep on running

\footnotetext{
${ }^{19}$ Correlation coefficients between the growth rates of materials and services offshoring with regards to that of employment are, respectively, -0.118 and 0.071 .

${ }^{20}$ In particular, Hattori and Miyazaki (2000) and Yoshikawa and Matsumoto (2001), who consider a production technology with constant returns to scale and perfect competition in both output and input markets, obtain respectively the following numbers: $1.20 \%$ (1987-1993) and -0.60\% (1994-1997), and 1.20\% (1980-1990) and -0.90\% (1990-1998). Both works rely on value-added measures. See also Fukao and Kwon (2006) for further references on Japan's TFP growth in the 1990s.
} 
due to bad loan practices encouraged by permissive banks. This, consequently, prevents more productive companies from gaining market share (Ahearne and Shinada, 2005) since the competitive outcome where zombies lay off workers and lose their share no longer holds (Caballero et al., 2008, and Kobayashi, 2007). More, the Japanese government helped in delivering a noncompetitive outcome during the 1990s through its soaring debt and large bailouts targeting a financial sector already damaged by the bubble crisis (Agnese and Sala, 2008). In more general terms, and following Fukao and Kwon (2006), we can distinguish between those who find the disappointing performance of the 1990s in a lack of effective demand and a liquidity trap-deflation cycle (Yoshikawa, 2003; Fukao, 2003), from those who identify supply-side factors as major determinants (Hayashi and Prescott, 2002).

\subsection{How Good are the Offshoring Measures?}

To answer this question I carry out a decomposition analysis over time (1980-2005) and at the country level in a rather conventional way. The analysis involves following the "within" and "between" exercise to account for variations in, respectively, the industries' offshoring intensity and their shares in total production. ${ }^{21}$ Decomposing the variance turns out to be helpful in isolating the changes in the offshoring intensities within industries from the changes in the production shares between them. Thus, it is easy to see what proportion of the change in the index is due to either a change in real offshoring or a change in the industries' relative weights in the economy. The country index (Tables A3 to A5) might as well be picking up structural influences that have nothing to do with offshoring.

Therefore, to see to what extent the index describes the phenomenon accurately, I move on to extract the sources of growth using the following expression:

$$
\Delta \Phi^{80-05}=\Delta \sum_{i}^{n} \theta_{i} \delta_{i}=\sum_{i}^{n} \overline{\theta_{i}} \Delta \delta_{i}+\sum_{i}^{n} \overline{\delta_{i}} \Delta \theta_{i} ; \Phi=\text { OS M OS S }
$$

where the change in the offshoring index at the country level $(\Phi)$ is decomposed, throughout industries (i), into the change in the offshoring intensity (the within term) and the change in the share of total production (the between term). The former fixes the structural component of industries, also the share of industry output to total output $(\theta)$, to focus on the change in the offshoring intensity $(\delta)$. The latter, contrariwise, fixes the offshoring component, thus capturing the contribution of the structural component to the change in the index. A bar over the variables defines the mean for the period under study.

Table A7 breaks down the sources of growth for the index during the whole sample and in two subsamples (1980-1990 and 1990-2005). With the exception of the last column, all numbers are the increases and drops in the indices, in percentage points, that could be derived from tables A3, A4, and A5. The column labeled "within" captures the change in the index that is due to changes in the offshoring intensities of industries alone, while the column labeled "between" seizes the change in the index that corresponds to a change in the production shares. The contributions of each component are summed up under "total", and refer to the total change, in percentage points, in the indices shown before. For instance, during 1980-2005, the increase in the OSM index for the whole economy was 7.67 percentage points (see table A3), of which 7.87 correspond to a change in the offshoring intensity and -0.20 to a change in the structural

\footnotetext{
${ }^{21}$ See Hummels et al. (2001), Strauss-Kahn (2004), and Horgos (2008), who also undertake decomposition analyses along these lines.
} 
component. Lastly, the "within/total" column focuses on the proportion of the change in the index that is exclusively explained by a change in offshoring intensity.

In general, we can see that the changes in the offshoring intensity across all branches of activities account for most of the growth in overall offshoring, as shown in Tables A3, A4, and A5. The structural components have hardly any incidence on the indices, especially prior to the "lost decade". After 1990 the ratios in the last column behave less consistently and deviate a bit from the 100 percent benchmark. Naturally, we should expect the economic turmoil in the 1990s to produce some changes in the sector composition of the Japanese economy. All in all, for every categorization, the index performs acceptably well for the whole sample yet less smoothly during the fading 1990 s.

\subsection{Econometric Analysis}

Having determined the suitability of the index, I now proceed to gauge the effects on the Japanese economy relying on panel data analysis. Panel studies have the advantage over simple cross-section data studies in one important aspect: cross-section surveys do not provide enough information about earlier time periods (Bond, 2002). On the other hand, purely aggregated time series analyses might obscure the microeconomic dynamics and make the underlying aggregation bias even more severe. As opposed to these techniques, panels offer a wider scope to examine the heterogeneity in adjustment dynamics between firms or industries (Bond, 2002). Thus, as stated before, potential effects of offshoring basically come down to those related to employment and productivity. The analysis below is therefore divided accordingly, and follows the methodology developed above. Table A8 provides the summary statistics of the main variables and, due to data cleaning, we are finally left with 83 industries.

Under our industry setting we should expect, a priori, that we are dealing with a heterogeneous dataset in the sense that there are perceptible differences between estimated cross-sections (e.g. different constants) that could be exploited. Heterogeneity bias usually implies the inclusion of either fixed or random effects which can capture these differences better than a pooled estimation. ${ }^{22}$ Finally, addressing the endogeneity of the offshoring variable becomes important since it might not be random which industries engage more in this practice. If the same industries engage in offshoring all over the sample then industry fixed effects should work fine. That is hardly the case though, and the endogeneity of the offshoring variable turns out further magnified due to the presence of measurement errors. For this reason, in addition to fixed effects estimates I deem it necessary to rely on GMM estimation since the former might turn biased and inconsistent. Hence, to remove the permanent industry-specific effects I need to transform the equations into first-differences (Arellano and Bond, 1991) or orthogonal deviations (Arellano and Bover, 1995). Potential measurement problems underlying the

\footnotetext{
${ }^{22}$ Enough to say that the F-test consistently rejected the $\mathrm{H} 0$ of homogeneous intercepts for most of our equations, so the fixed effects (dummy variables) estimation is preferred to pooling. Results on these tests are available on request. The F-test used is:

$F=\frac{\left(R_{F E}^{2}-R_{P O L S}^{2}\right) /(N-1)}{\left(1-R_{F E}^{2}\right) /(N T-N-K)} \sim F_{(N-1, N T-N-K)}$

Furthermore, being this a big panel (relatively large $\mathrm{N}$ and $\mathrm{T}$ ) the difference between fixed and random effects should eventually fade away (Hsiao, 2003), so the latter are avoided. See for example Ahn and Moon (2003) for the properties of large-N, large-T panels.
} 
offshoring index would lead us to opt for the latter, since first-differencing tends to amplify such problems through larger variances.

All specifications have been reparametrized so as to show the total effects concentrated in period $t$, while joint Wald tests are presented along the estimations to assure that this is possible. Further, some specifications include time dummies to control for period specific shocks common to all industries. For the GMM, these time dummies are also used as additional instruments. In addition to the predetermined instruments I too consider exogenous ones. ${ }^{23}$ The validity of the instrument set and of the overidentifying restrictions are tested using the conventional Sargan test. The consistency of the GMM estimates also depends on the absence of serial correlation in the errors. Using the estimates from the model in orthogonal deviations I test the absence of second-order serial correlation in the residuals, as proposed by Arellano and Bond (1991).

\subsubsection{Employment Effects}

To capture the employment effects of offshoring I estimate the conditional and unconditional labor demand equations in (8) and (8'), as done frequently in the literature. ${ }^{24}$ Results for the whole economy are shown in tables A9 to A12. Estimations on the manufacturing and services sectors considered separately are displayed in tables A13 and A14 for the former and A15 for the latter. Finally, in table A16 I estimate our labor demand in equation (9), which omits the output variables and includes the real stock of capital. All the equations are characterized by a large persistence coefficient, indicating a strong inertia in the industries' aggregate level of employment. $^{25}$ Our variables of interest are OSS and OSM, and since these are not transformed into logarithms, they should be interpreted as semi-elasticities.

The conditional labor demand in table A9 shows a small negative effect of materials offshoring in the fixed effects estimation. The coefficient turns out significant at a 5 percent. In particular, a 1 percentage point increase in the index of materials offshoring comes to explain a fall, in average, of 0.04 percent in the industries' domestic employment. Further, when considering the GMM estimator I find a surprisingly large effect of services offshoring. Here, a 1 percentage point increase of the services offshoring index explains between a 2 and 3 percent increase in employment. At first we might think that this large effect is driven by the existence of outliers, especially, by rapidly growing activities such as the video and sound industry and the

\footnotetext{
${ }^{23}$ Predetermined variables used as instruments for the conditional labor demand equations were the same in all specifications, namely: $L_{i t-2}, L_{i t-3}, w_{i t-2}, w_{i t-3}, Y_{i t-2}, Y_{i t-3}$, all in logs. For the unconditional version we have: $L_{i t-2}, L_{i t-3}, w_{i t-2}, w_{i t-3}, p_{i t-2}^{Y}, p_{i t-3}^{Y}$, all in logs. For total factor productivity I use $T F P_{i t-2}, T F P_{i t-3}$. Exogenous instruments for all GMM estimations were the office and production workers industry shares (also from the JIP database). Office workers are thought to be more related with services offshoring whereas production workers are often linked to materials offshoring.

${ }^{24}$ For estimating purposes we here relax the hypothesis of constant returns to scale, so our demand factor equation in (13) is derived from a production function of the general form $Y_{i}=A(t) K_{i}^{\alpha} L_{i}^{\beta}$.

${ }^{25}$ The Wald test for the lagged employment coefficient being equal to 1 is rejected in most of the specifications. Moreover, Im-Pesaran-Shin tests for the existence of unitary roots were run individually on the cross-sections residuals, rejecting in most cases the null of a root process (the results of these tests are available on request). Related to this, Agnese and Sala (2008) estimate a system for Japan consisting of a labor demand and a labor supply equations. Even though offshoring is not considered there, the labor demand equation appears with a persistence coefficient of 0.89 .
} 
information and internet services industry. ${ }^{26}$ To solve for this I drop the potential outliers and then re-estimate the equations. The results are almost unchanged. It must also be observed that the last GMM equation passes both the Sargan and $\mathrm{m} 2$ tests (though the latter does so at the margin). Not rejecting the Sargan test is indicative of the exogeneity of the instruments used, while failing to reject the $\mathrm{m} 2$ test implies the absence of second-order autocorrelation. This is not always so, yet the GMM specification in the last column is generally preferred in all labor demand equations.

Controlling now for the scale effect in table A10, I substitute in the GDP price index for its volume measure. This would allow offshoring to affect employment indirectly through productivity gains. The results presented here seem to confirm those from table A9. However, we can see now how the employment effects of both services and materials offshoring are somewhat larger than before. The last specification presents a strong problem of (second-order) autocorrelation though.

As in Cadarso et al. (2008), tables A11 and A12 replace the dependent variable "employed persons" by "hours worked". Here again we have, for the conditional function, a significant yet rather small negative effect of materials offshoring in all specifications and a relatively large effect of services offshoring in the GMM specifications. As before, for the unconditional version the effects turn out larger and, in particular, the fixed effects estimation shows a negative effect of services offshoring (this is generally not the case, as we can see from the rest of the tables).

Evidence for the manufacturing sector alone is presented in tables A13 and A14. For the conditional demand we have that in the fixed effects equations materials offshoring is negative and significant, yet small in size. Also, the coefficients of services offshoring turn out large and strongly significant in all equations. In turn, the Sargan and $\mathrm{m} 2$ tests are passed easily. For the unconditional demand we produce similar results.

Zooming into the data of table A15 we get the services sector in detail. Contrary to what we had before, the evidence here suggests a negative impact of services offshoring in the fixed effects equations with and without period dummies. The evidence presented on this table and the previous two suggests that, at least at the aggregate level, the more related the sector to one type of offshoring, the more it affects domestic employment negatively. Thus, services offshoring would most probably produce negative effects within the services sector whereas materials offshoring would do so within the manufacturing sector. It is also to note that GMM specifications could not be calculated at this point.

Table A16 shows our last labor demand equation, which corroborates our previous results for the whole economy. The specification without period dummies passes both the Sargan and $\mathrm{m} 2$ tests (albeit the Sargan does it only marginally), whereas the specification including period effects presents autocorrelation. Services offshoring affects employment positively in both these estimations, with an overall short-run elasticity of approximately 3.5 percent. Materials offshoring has in turn a negative effect, with an overall short-run elasticity that goes from -0.39 to -0.27 percent, depending on whether period effects are being considered. For this particular equation, long run elasticities are 47 (no period dummies) and 35 percent (period dummies) for services offshoring and -5.11 (no period dummies) and -2.64 percent (period dummies). The results here are also robust to the presence of outliers. Furthermore, potential endogeneity

\footnotetext{
${ }^{26}$ For the big push in terms of employment that these two industries represented in later years refer to table A6.
} 
issues are minimized not only by the use of the GMM technique, but by the ruling out of output variables in the right-hand side of the labor demand equation.

\subsubsection{Productivity Effects}

Estimating a panel for both equations (10) and (11), and the using (14) and (15), I extract the TFP measures and carry out the estimation of equations (16) and (17). ${ }^{27}$ Table A17 shows the results for the whole economy, this time not including the fixed effects estimations for ease of presentation. As argued before, our variables of interest are believed to be determined endogenously. Moreover, to avoid omitted variables biases I follow Hijzen et al. (2006) and try to control for the R\&D expenditure, which is a natural driver of the productivity growth. Since this variable does not come with the JIP database, I decide to use a proxy instead. This is the investment in information technologies; particularly, the real value of the investment in software by industries. We expect this to have generally a positive effect on the TFP growth rate, yet for our dataset it does not turn out significant, so it is finally left aside.

Both the equations display a low level of persistence of the lagged dependent variable, so the growth rate of productivity is not strongly contingent on its past values. We should also note that both measures put the stress on different dimensions of the production process. ${ }^{28}$ Notice that the value-added TFP displays a higher variance throughout the sample (see table A8). In analyzing the estimation of the value-added measure through equation (16) we have that, for the specification without period effects, services offshoring is large and significant while materials offshoring turns out with a significant negative sign yet a rather small net effect. If we add period dummies we end up with both kinds of offshoring having a positive effect on productivity growth, yet only for materials is significant. Moreover, the estimation entertaining period dummies loosely passes both the Sargan and $\mathrm{m} 2$ test. Here, a 1 percentage point rise in the materials offshoring index yields a 0.35 percent increase in the TFP growth rate.

In the estimation of the TFP output-based measure in equation (17) we have a similar picture. Services offshoring appears with a large positive effect in the specification without period effects, yet there is some evidence of second order autocorrelation. As for the estimation considering period effects, materials offshoring turns out positive and significant and again, both the Sargan and $\mathrm{m} 2$ test are easily passed. According to this, a 1 percentage point expansion in materials offshoring would bring about a 0.32 percent increase in the TFP growth rate.

\footnotetext{
${ }^{27}$ For estimating purposes I relax the constant returns hypothesis once again. In relation to this, Miyagawa et al. (2006) find that even if we relax the constant returns to scale hypothesis and allow for variable returns and externalities, constant returns to scale are observed in most of the 37 industries of their database. In other words, the cyclicality of the Solow residual lies in pure technological shocks. Furthermore, Wakita (2006) reveals that for Japan in the lost decade labor shares were almost constant (there were some changes due to depreciation though), thus implying that even in the presence of imperfect competition and/or nonconstant returns to scale, TFP accounting measures would remain equal. It is left to see if they are equally as bad, in which case a more general production function should be needed (see Kee, 2004). This however escapes the scope of the paper.

${ }^{28}$ The correlation coefficient is 0.90 however.
} 


\section{Conclusions}

Usual fears around this hot subject entail, above all, the loss of domestic jobs that are now being imported in greater numbers. It is true that as even more services become tradable (especially with the exponential growth of communications and Internet), more jobs will be at risk of being moved abroad. But this argument loses sight of the other side of the story, namely, that new jobs might be created locally due to a productivity boost or in response of economic scarcity. We have seen in this paper how offshoring might hold the key as regards employment creation and productivity improvement, something Japan is desperately in need for.

In order to provide a full-fledged account of the issue for Japan, this paper first reviews the main literature and finds its applicability to our special case, then analyzes the measurement issues to assess the phenomenon adequately, and finally offers an econometric analysis for the whole economy during the period 1980-2005. Manufacturing as well as services industries are here considered, and both materials and services offshoring are brought into the analysis. The data show materials offshoring to be of much greater importance than services offshoring, in spite of the communications revolution tapping in every corner of the globe. Moreover, with the ghost of the lost decade still looming over the economy, services offshoring keeps on being pulling down to rather modest levels. Enough to say that its growth rate was slightly higher than that of materials' during the 1980s, just to recede during the 1990s in a considerable proportion (in fact, the average annual rate was negative during the 1990s and onwards).

Notwithstanding the little size of the services offshoring measure, the regression results suggest a large positive employment effect which ranges from 2 to 4 percent, as a result of a 1 percentage point increase in the index. Materials offshoring, in turn, appears with a negative sign in most of the specifications, yet the coefficients are of small size. In general, these results are robust to the presence of outliers in the data and to the different specifications of the dynamic labor demand (whether it refers to control variables or the dependent variable). Our last labor demand equation is often preferred as it solves for the endogeneity problem most certainly found in specifications considering the output variable explicitly.

Splitting the database into manufacturing and services sectors seems to point to the final effect of offshoring as depending on both the type of offshoring and the characteristics of the sector. For instance, materials offshoring to affect employment negatively within the manufacturing sector, and services offshoring to do the same within the services sector. Also, when crossing these features positive effects might be expected. This is of course a very preliminary result and demands further research on the subject. The next step is analyzing the effects of offshoring on an industry-by-industry basis.

On the other hand, positive productivity effects are also observed. Here the coefficients associated to both types of offshoring turn up with a net positive sign most of the times. However, the specifications considering time dummies and portraying materials offshoring with a positive effect are preferred (both the Sargan and $\mathrm{m} 2$ are passed). There, the effect goes from a 0.35 percent increase in the value-added- based TFP growth rate, to a 0.32 percent increase in the gross output-based TFP growth rate, being explained by a 1 percentage point expansion in the index of materials offshoring.

The empirical work laid out in this paper points to the direction of potential gains due to offshoring, both in employment and productivity terms. As seen here, the realization of the principle of comparative advantages does not escape our analysis if we consider offshoring as a particular form of trade. However, one is left to wonder how much it will take for policy-

IESE Business School-University of Navarra - 23 
makers to really comprehend this fact and stop hindering the natural process of profit-seeking and efficiency-seeking. Or perhaps we are hopeless against the interventionist wave that spreads like gunpowder these days. But in any case, hope dies last. 


\section{Appendix A: Tables and Figures}

\section{Table A1: Offshoring on Employment, Wages, and Productivity}

Empirical evidence (selected works)

\begin{tabular}{|c|c|c|c|}
\hline \multicolumn{2}{|l|}{ Not significant } & \multicolumn{2}{|l|}{ Significant } \\
\hline Aggregate & Country & Aggregate & Country \\
\hline Siegel and Griliches (1992)‡ & United States & Feenstra and Hanson (1996a, b)† & United States \\
\hline Berman et al. (1994) & United States & Feenstra and Hanson (1999)† & United States \\
\hline Amiti and Wei $(2005)^{*}$ & United Kingdom & Egger and Egger $(2003,2005)$ & Austria \\
\hline Ekholm and Hakkala (2006) & Sweden & Strauss-Kahn (2004) & France \\
\hline Cadarso et al. (2008) & Spain & $\begin{array}{l}\text { Amiti and Wei (2006) } \ddagger^{*} \\
\text { Hijzen et al. (2005) } \\
\text { Canals (2006) } † \\
\text { Ekholm and Hakkala (2006) } \\
\text { Cadarso et al. (2008) }\end{array}$ & $\begin{array}{l}\text { United States } \\
\text { United Kingdom } \\
\text { United States } \\
\text { Sweden } \\
\text { Spain }\end{array}$ \\
\hline Disaggregate & & Disaggregate & \\
\hline Siegel and Griliches (1992)‡ & United States & Head and Ries (2002) & Japan \\
\hline Slaughter $(1995,2000)$ & United States & Egger et al. (2003) & Austria \\
\hline Hakkala et al. (2007) & Sweden & $\begin{array}{l}\text { Girma and Görg (2004)‡ } \\
\text { Criscuolo and Leaver }(2005) \ddagger^{*} \\
\text { Geishecker and Görg (2005)† } \\
\text { Görg and Hanley (2005)* } \\
\text { Hijzen et al. }(2006) \ddagger \\
\text { Crinò }(2007)^{*}\end{array}$ & $\begin{array}{l}\text { United Kingdom } \\
\text { United Kingdom } \\
\text { Germany } \\
\text { Ireland } \\
\text { Japan } \\
\text { United States }\end{array}$ \\
\hline
\end{tabular}

Note: the estimated equations consider either employment or relative employment, or $\dagger$ : relative wages and /or $\$$ : productivity; *: adds services offshoring to the study. Disaggregate refers to those studies undertaken below the industry level: firms, establishments, or individuals. 


\section{Table A2: JIP Database, Economic Branches of Activity}

\begin{tabular}{|c|c|c|c|c|c|}
\hline JIP Code & Manufacturing & JIP Code & Services & JIP code & Other \\
\hline 008 & Livestock products & 067 & Wholesale & 001 & Rice, wheat production \\
\hline 009 & Seafood products & 068 & Retail & 002 & Miscellaneous crop farming \\
\hline 010 & Flour and grain mill products & 069 & Finance & 003 & Livestock and sericulture farming \\
\hline 011 & Miscellaneous foods & 070 & Insurance & 004 & Agricultural services \\
\hline 012 & Animal foods \& fertilizers & 071 & Real estate & 005 & Forestry \\
\hline 013 & Beverages & 072 & Housing & 006 & Fisheries \\
\hline 014 & Tobacco & 073 & Railway & 007 & Mining \\
\hline 015 & Textile products & 074 & Road transportation & 062 & Electricity \\
\hline 016 & Lumber and wood products & 075 & Water transportation & 063 & Gas, heat supply \\
\hline 017 & Furniture and fixtures & 076 & Air transportation & 064 & Waterworks \\
\hline 018 & Pulp, paper, and other paper & 077 & Other transportation & 065 & Water supply for industrial use \\
\hline 019 & Paper products & 078 & Telegraph and telephone & 066 & Waste disposal \\
\hline 020 & Printing, and plate making & 079 & Mail & & \\
\hline 021 & Leather and leather products & 080 & Education (private and non-p) & & \\
\hline 022 & Rubber products & 081 & Research (private) & & \\
\hline 023 & Chemical fertilizers & 082 & Medical (private) & & \\
\hline 024 & Basic inorganic chemicals & 083 & Hygiene (private and non- $p$ ) & & \\
\hline 025 & Basic organic chemicals & 084 & Other public services & & \\
\hline 026 & Organic chemicals & 085 & Advertising & & \\
\hline 027 & Chemical fibers & 086 & Rental of office equipment & & \\
\hline 028 & Miscellaneous chemical pdts. & 087 & Automobile maintenance & & \\
\hline 029 & Pharmaceutical products & 088 & Other services for businesses & & \\
\hline 030 & Petroleum products & 089 & Entertainment & & \\
\hline 031 & Coal products & 090 & Broadcasting & & \\
\hline 032 & Glass and its products & 091 & Information and Internet ss & & \\
\hline 033 & Cement and its products & 092 & Publishing & & \\
\hline 034 & Pottery & 093 & Video and sound & & \\
\hline 035 & Miscellaneous ceramic & 094 & Eating and drinking places & & \\
\hline 036 & Pig iron and crude steel & 095 & Accommodation & & \\
\hline 037 & Miscellaneous iron and steel & 096 & Laundry, beauty services & & \\
\hline 038 & Smelting non-ferrous metals & 097 & Other services for individuals & & \\
\hline 039 & Non-ferrous metal products & 098 & Education (public) & & \\
\hline 040 & Metal products & 099 & Research (public) & & \\
\hline 041 & Miscellaneous metal products & 100 & Medical (public) & & \\
\hline 042 & General industry machinery & 101 & Hygiene (public) & & \\
\hline 043 & Special industry machinery & 102 & Ss. ins. \& ss. welfare (public) & & \\
\hline 044 & Miscellaneous machinery & 103 & Public administration & & \\
\hline 045 & Office and industry machines & 104 & Medical (non-profit) & & \\
\hline 046 & Electrical and ind. apparatus & 105 & Ss. Ins. \& ss. welfare (non-p) & & \\
\hline 047 & Household electric appliances & 106 & Research (non-profit) & & \\
\hline 048 & Electronics, computer eqpmnt. & 107 & Other (non-profit) & & \\
\hline 049 & Communication equipment & 108 & Activities not classified & & \\
\hline 050 & Measuring instruments & & & & \\
\hline 051 & Semiconductor and circuits & & & & \\
\hline 052 & Electronic parts & & & & \\
\hline
\end{tabular}

Source: JIP Database $(2006,2008)$. RIETI, Hitotsubashi University, and ESRI, Japan. 
Figure A1: Manufacturing and services offshoring (\%)

1980-2005

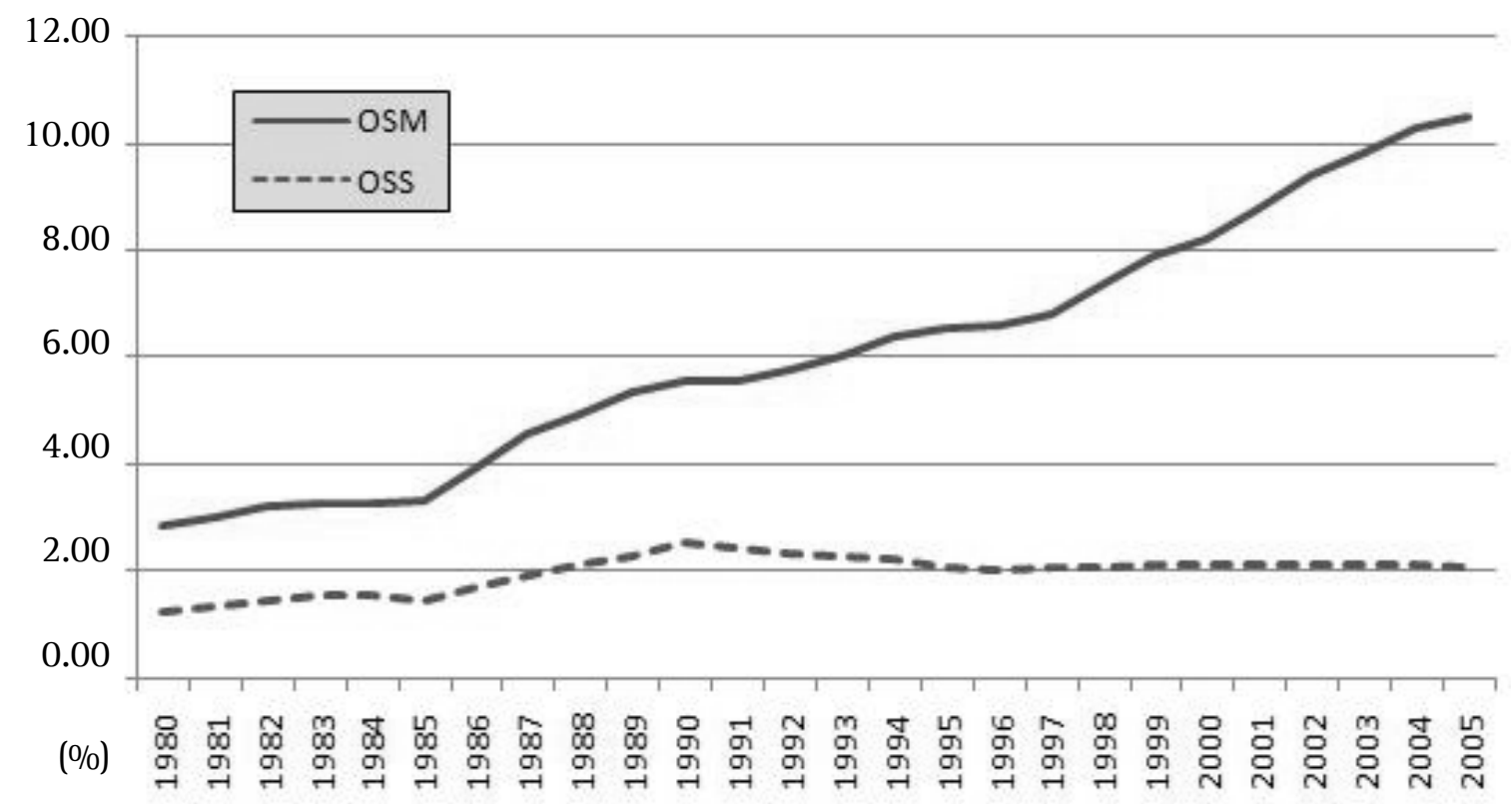

Note: Japan's manufacturing and services offshoring indices (OSM, OSS) according to formula (1).

Broad measures, weighted by industry value-added (JIP Database). See also Tables A3 to A5 below. 
Table A3: Offshoring Intensity, whole economy 1980-2005

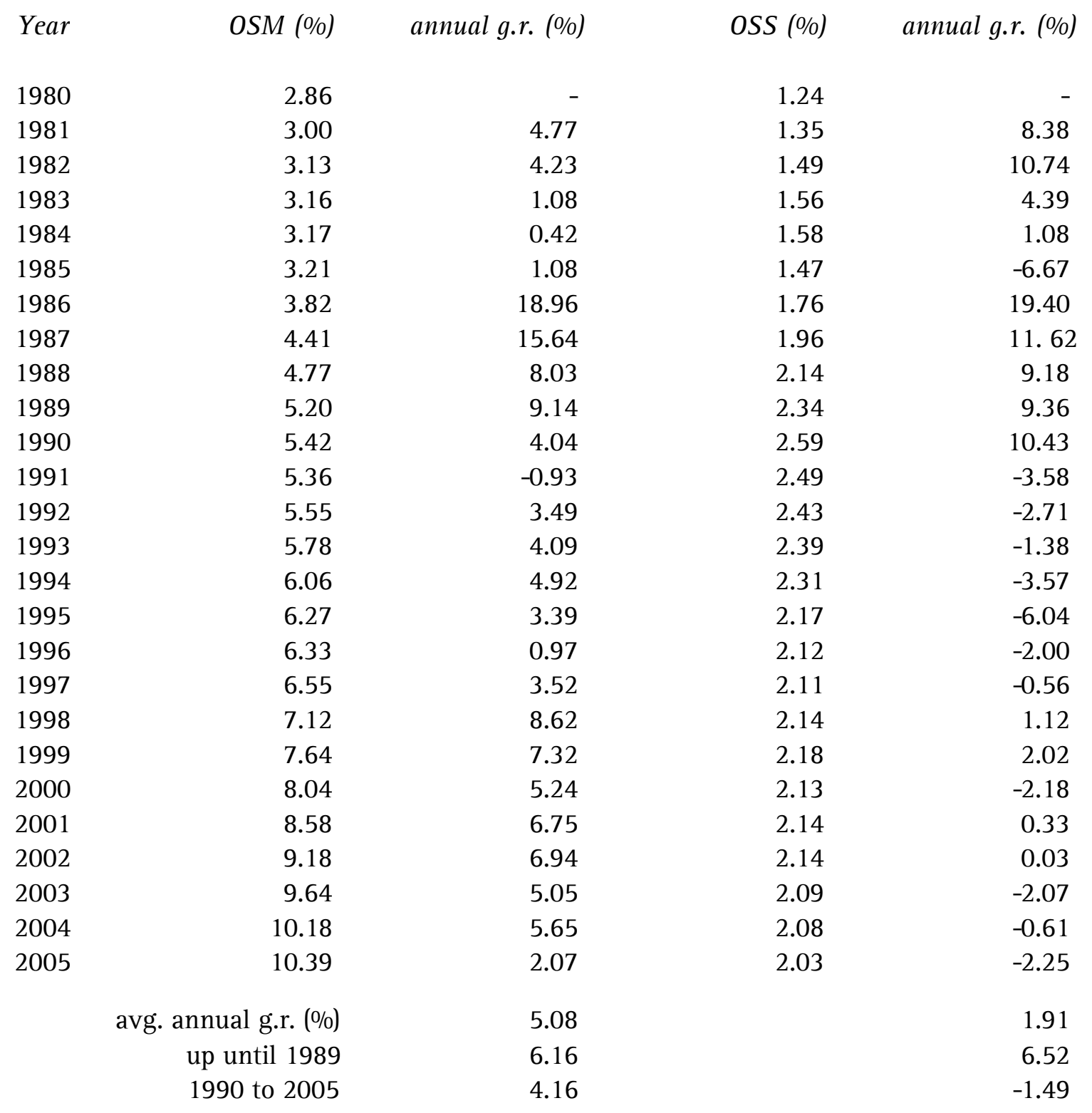


Table A4: Offshoring Intensity, manufacturing industries 1980-2005

\begin{tabular}{|c|c|c|c|c|}
\hline Year & OSM (\%) & annual g.r. (\%) & OSS (\%) & annual g.r. (\%) \\
\hline 1980 & 3.81 & - & 1.44 & - \\
\hline 1981 & 4.18 & 9.51 & 1.52 & 6.21 \\
\hline 1982 & 4.67 & 11.70 & 1.68 & 10.47 \\
\hline 1983 & 4.90 & 4.97 & 1.77 & 4.87 \\
\hline 1984 & 5.01 & 2.26 & 1.80 & 1.66 \\
\hline 1985 & 5.14 & 2.72 & 1.67 & -6.96 \\
\hline 1986 & 5.85 & 13.78 & 1.96 & 17.12 \\
\hline 1987 & 6.61 & 12.97 & 2.15 & 9.99 \\
\hline 1988 & 6.94 & 4.89 & 2.34 & 8.51 \\
\hline 1989 & 7.45 & 7.43 & 2.53 & 8.52 \\
\hline 1990 & 7.55 & 1.35 & 2.71 & 6.78 \\
\hline 1991 & 7.53 & -0.29 & 2.47 & -8.65 \\
\hline 1992 & 7.69 & 2.05 & 2.36 & -4.65 \\
\hline 1993 & 8.16 & 6.16 & 2.31 & -2.00 \\
\hline 1994 & 8.88 & 8.84 & 2.21 & -4.43 \\
\hline 1995 & 9.18 & 3.37 & 2.06 & -6.66 \\
\hline 1996 & 8.99 & -2.09 & 2.03 & -1.28 \\
\hline 1997 & 9.05 & 0.65 & 2.04 & 0.49 \\
\hline 1998 & 9.54 & 5.41 & 2.07 & 1.37 \\
\hline 1999 & 10.05 & 5.41 & 2.13 & 3.02 \\
\hline 2000 & 9.88 & -1.75 & 2.18 & 2.10 \\
\hline 2001 & 10.31 & 4.36 & 2.21 & 1.34 \\
\hline 2002 & 10.48 & 1.63 & 2.22 & 0.73 \\
\hline 2003 & 10.58 & 0.96 & 2.26 & 1.62 \\
\hline 2004 & 10.79 & 2.06 & 2.27 & 0.35 \\
\hline 2005 & 10.60 & -1.83 & 2.24 & -1.11 \\
\hline & avg. annual g.r. (\%) & 4.01 & & 1.73 \\
\hline & up until 1989 & 6.93 & & 5.85 \\
\hline & 1990 to 2005 & 2.14 & & -1.17 \\
\hline
\end{tabular}


Table A5: Offshoring Intensity, services industries

1980-2005

\begin{tabular}{|c|c|c|c|c|}
\hline Year & OSM (\%) & annual g.r. (\%) & OSS (\%) & annual g.r. (\%) \\
\hline 1980 & 2.62 & - & 1.18 & - \\
\hline 1981 & 2.68 & 2.51 & 1.30 & 10.26 \\
\hline 1982 & 2.72 & 1.27 & 1.46 & 12.23 \\
\hline 1983 & 2.70 & -0.66 & 1.52 & 4.26 \\
\hline 1984 & 2.66 & -1.38 & 1.53 & 1.08 \\
\hline 1985 & 2.67 & 0.28 & 1.44 & -5.90 \\
\hline 1986 & 3.29 & 23.25 & 1.74 & 20.31 \\
\hline 1987 & 3.86 & 17.41 & 1.94 & 11.74 \\
\hline 1988 & 4.21 & 9.07 & 2.11 & 8.79 \\
\hline 1989 & 4.62 & 9.65 & 2.30 & 8.99 \\
\hline 1990 & 4.87 & 5.45 & 2.57 & 11.76 \\
\hline 1991 & 4.80 & -1.60 & 2.59 & 0.76 \\
\hline 1992 & 5.04 & 5.02 & 2.57 & -0.99 \\
\hline 1993 & 5.23 & 3.81 & 2.55 & -0.80 \\
\hline 1994 & 5.41 & 3.42 & 2.47 & -3.03 \\
\hline 1995 & 5.61 & 3.74 & 2.32 & -6.21 \\
\hline 1996 & 5.72 & 2.00 & 2.26 & -2.49 \\
\hline 1997 & 5.99 & 4.76 & 2.22 & -1.72 \\
\hline 1998 & 6.62 & 10.48 & 2.22 & 0.22 \\
\hline 1999 & 7.15 & 8.02 & 2.27 & 1.84 \\
\hline 2000 & 7.62 & 6.52 & 2.17 & -4.21 \\
\hline 2001 & 8.17 & 7.19 & 2.17 & -0.18 \\
\hline 2002 & 8.83 & 8.16 & 2.15 & -0.81 \\
\hline 2003 & 9.36 & 6.00 & 2.06 & -4.00 \\
\hline 2004 & 9.91 & 5.83 & 2.03 & -1.48 \\
\hline 2005 & 10.21 & 3.03 & 1.97 & -2.88 \\
\hline & avg. annual g.r. (\%) & 5.37 & & 2.01 \\
\hline & up until 1989 & 5.85 & & 6.94 \\
\hline & 1990 to 2005 & 4.73 & & -1.65 \\
\hline
\end{tabular}




\section{Table A6: Offshoring and Employment Growth}

1980-2005

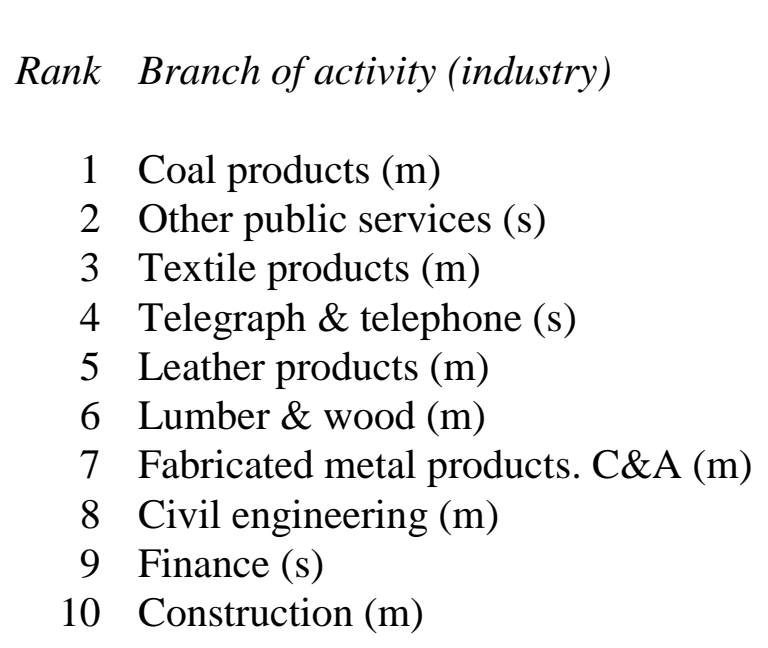

$\begin{array}{ccc}\text { OSM } & \text { Empl. } & \text { Rank } \\ \text { avg.g.r. }(\%) & \text { avg. g.r. }(\%) & \text { Empl. } \\ & & \\ 9.16 & -5.15 & 106 \\ 9.14 & -0.56 & 64 \\ 8.71 & -4.24 & 98 \\ 8.25 & -2.07 & 82 \\ 7.85 & -3.16 & 91 \\ 7.83 & -3.77 & 95 \\ 7.53 & -0.99 & 73 \\ 7.43 & -0.53 & 63 \\ 7.27 & 0.08 & 49 \\ 7.14 & 0.10 & 47\end{array}$

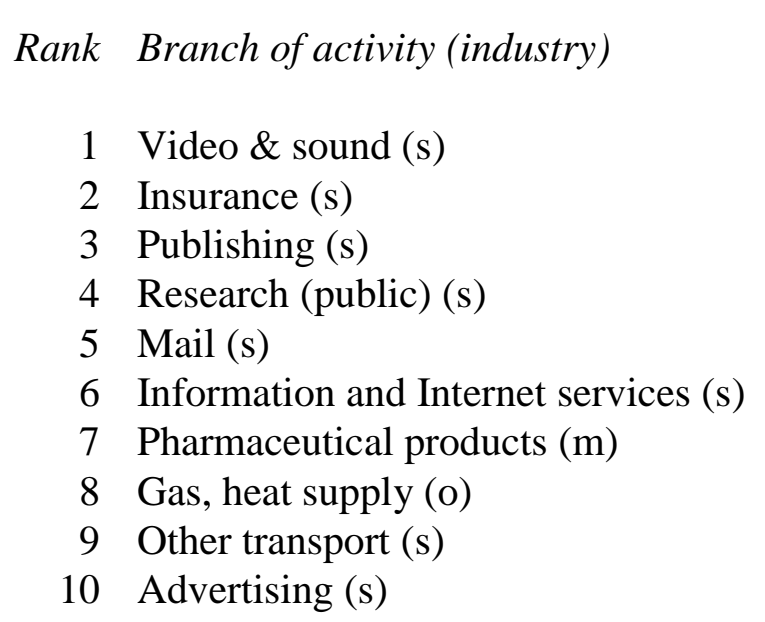

$\begin{array}{ccc}\text { OSS } & \text { Empl. } & \text { Rank } \\ \text { avg.g.r. }(\%) & \text { avg.g.r. }(\%) & \text { Empl. }\end{array}$

$\begin{array}{lcc}6.48 & 11.16 & 1 \\ 6.31 & -0.16 & 53 \\ 5.11 & -0.16 & 54 \\ 4.97 & 0.38 & 40 \\ 4.81 & 1.25 & 25 \\ 4.70 & 9.83 & 2 \\ 4.64 & -0.06 & 51 \\ 4.54 & -0.87 & 70 \\ 4.52 & 1.42 & 23 \\ 4.43 & 0.65 & 33\end{array}$

Note: as in Table A2 industries are divided in manufacturing (m), services (s), and other (o). Average growth rates are smoothed annualized changes derived from a compound index. 
Figure A2: Total Factor Productivity, Growth Rate (\%)

1980-2005

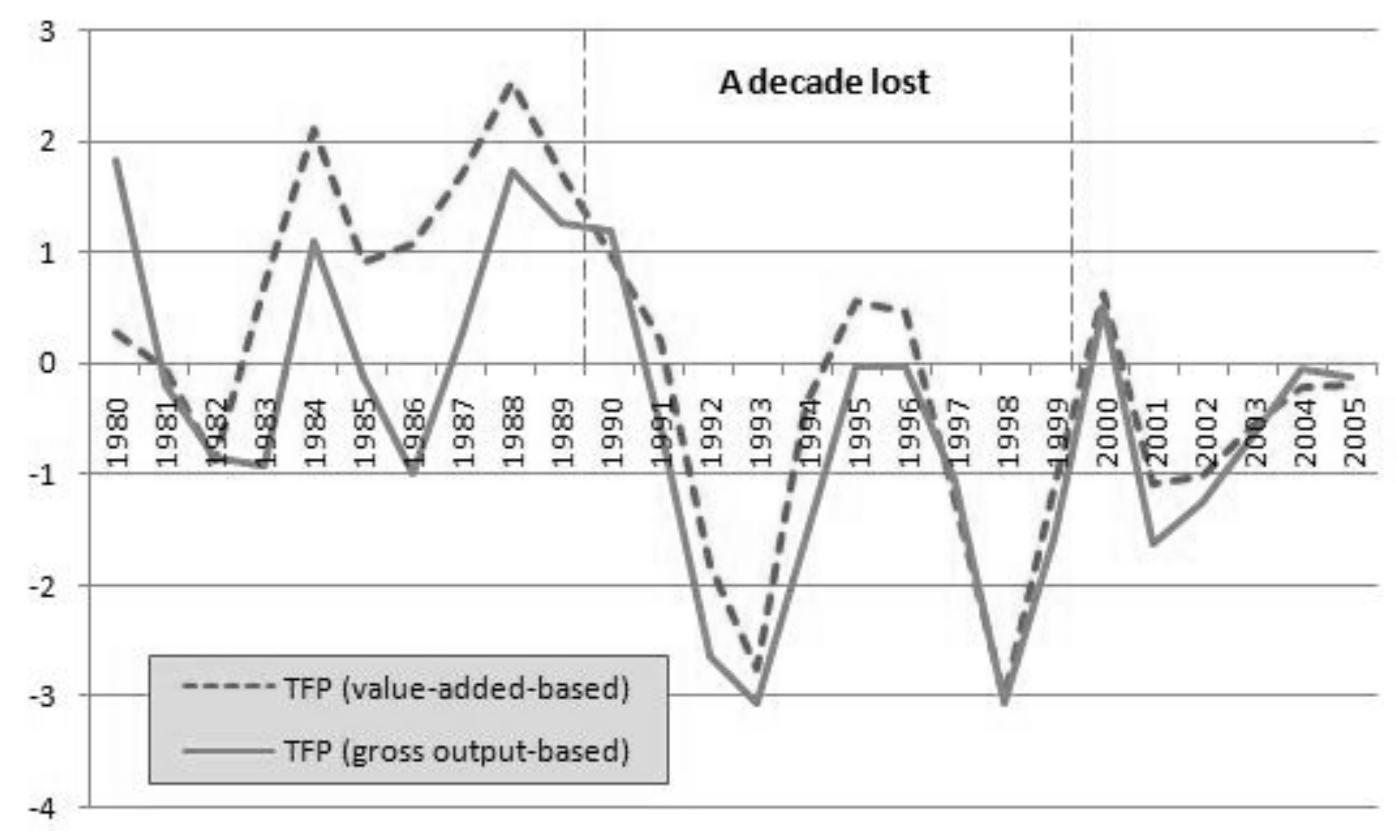

$\Delta(\%)$

Note: Calculated by equations (14) and (15); weighted by industry value-added and gross output. 
Table A7: Sources of Growth of the Offshoring Index

1980-2005

\begin{tabular}{|c|c|c|c|c|}
\hline $\begin{array}{r}\text { Whole economy } \\
\text { (Table A3) } \\
\text { OSM }\end{array}$ & Within & Between & Total $(w+b)$ & Within/Total \\
\hline 1980-1990 & 2.77 & -0.05 & 2.72 & $101.8 \%$ \\
\hline $1990-2005$ & 5.13 & -0.19 & $\underline{4.94}$ & $103.8 \%$ \\
\hline $1980-2005$ & 7.87 & -0.20 & 7.67 & $102.6 \%$ \\
\hline \multicolumn{5}{|l|}{ OSS } \\
\hline 1980-1990 & 1.29 & 0.01 & 1.30 & $99.1 \%$ \\
\hline 1990-2005 & -0.44 & -0.03 & $\underline{-0.47}$ & $93.5 \%$ \\
\hline 1980-2005 & 0.83 & 0.01 & 0.83 & $99.4 \%$ \\
\hline \multicolumn{5}{|l|}{$\begin{array}{r}\text { Manufacturing } \\
\text { (Table A4) } \\
\text { OSM }\end{array}$} \\
\hline 1980-1990 & 4.03 & -0.17 & 3.86 & $104.5 \%$ \\
\hline 1990-2005 & 3.94 & -0.76 & $\underline{3.18}$ & $124.0 \%$ \\
\hline 1980-2005 & 7.91 & -0.88 & 7.04 & $112.5 \%$ \\
\hline \multicolumn{5}{|l|}{ OSS } \\
\hline 1980-1990 & 1.23 & 0.00 & 1.23 & $99.7 \%$ \\
\hline 1990-2005 & -0.44 & 0.02 & $\underline{-0.42}$ & $105.5 \%$ \\
\hline 1980-2005 & 0.76 & 0.05 & 0.81 & $93.9 \%$ \\
\hline $\begin{array}{c}\text { Services } \\
\text { (Table A5) } \\
\text { OSM }\end{array}$ & & & & \\
\hline 1980-1990 & 2.34 & -0.06 & 2.27 & $102.7 \%$ \\
\hline 1990-2005 & 5.30 & 0.16 & $\underline{5.46}$ & $97.0 \%$ \\
\hline 1980-2005 & 7.61 & 0.12 & 7.73 & $98.5 \%$ \\
\hline \multicolumn{5}{|l|}{ OSS } \\
\hline 1980-1990 & 1.34 & 0.01 & 1.35 & $99.2 \%$ \\
\hline 1990-2005 & -0.43 & -0.06 & $\underline{-0.49}$ & $88.4 \%$ \\
\hline 1980-2005 & 0.87 & -0.01 & 0.86 & $101.7 \%$ \\
\hline
\end{tabular}

Note: numbers were rounded. Disaggregate results across industries are available on request. 


\section{Table A8: Summary Statistics}

1980-2005 (83 industries)

\begin{tabular}{cccccc} 
Variable & Observations & Mean & Max. & Min. & Std. $d v$. \\
\hline OSS $_{i t}(\%)$ & 2158 & 2.13 & 25.11 & 0.54 & 1.34 \\
OSM $_{i t}(\%)$ & 2158 & 8.03 & 114.12 & 0.62 & 12.58 \\
$L_{i t}($ workers $)$ & 2158 & 554,525 & $7,285,919$ & 1,767 & 983,150 \\
$\ln L_{i t}$ & 2158 & 12.33 & 15.80 & 7.47 & 1.41 \\
$H_{i t} *$ & 2158 & $1,067,583$ & $13,959,645$ & 3,358 & $1,876,792$ \\
$\ln H_{i t}$ & 2158 & 12.99 & 16.45 & 8.11 & 1.41 \\
$K_{i t}$ (real, million yen) & 2158 & $8,436,522$ & $123,477,018$ & 60,968 & $15,885,311$ \\
$\ln K_{i t}$ & 2158 & 15.11 & 18.63 & 11.01 & 1.20 \\
$w_{i t}($ avg., real, million yen) & 2158 & 5.15 & 34.84 & 0.33 & 3.38 \\
$\ln w_{i t}$ & 2158 & 1.45 & 3.55 & -1.10 & 0.61 \\
$Y_{i t} * *$ (real, million yen) & 2158 & $3,698,011$ & $43,061,121$ & 38,589 & $5,435,670$ \\
$\ln Y_{i t}$ & 2158 & 14.47 & 17.57 & 10.56 & 1.13 \\
$p^{Y}{ }_{i t}(2000=1)$ & 2158 & 1.06 & 5.93 & 0.42 & 0.32 \\
$\tau_{V i t}(\%)$ & 2158 & 0.08 & 38.85 & -45.47 & 6.49 \\
$\tau_{\text {Git }}(\%)$ & 2158 & -0.38 & 32.26 & -34.05 & 5.36 \\
\hline
\end{tabular}

*: 1000 workers $\times$ total annual working hours.

**: this refers to gross value-added. 


\section{Table A9: Conditional Labor Demand}

Whole economy (83 industries)

Dependent variable: $\ln L_{i t}$

\begin{tabular}{|c|c|c|c|}
\hline & FE & GMM & GMM \\
\hline $\ln L_{i t-1}$ & $\begin{array}{c}0.9492 * * * \\
(0.0057)\end{array}$ & $\begin{array}{c}0.8609 * * * \\
(0.0248)\end{array}$ & $\begin{array}{c}0.9016 * * * \\
(0.0210)\end{array}$ \\
\hline $\ln w_{i t}$ & $\begin{array}{c}-0.0450 * * * \\
(0.0054)\end{array}$ & $\begin{array}{c}-0.1257 * * * \\
(0.0274)\end{array}$ & $\begin{array}{c}-0.0887 * * * \\
(0.0210)\end{array}$ \\
\hline$\Delta \ln w_{i t}$ & $\begin{array}{c}-0.1249 * * * \\
(0.0097)\end{array}$ & $\begin{array}{c}-0.0753 * * * \\
(0.0200)\end{array}$ & $\begin{array}{c}-0.0922 * * * \\
(0.0172)\end{array}$ \\
\hline$O S S_{i t} / 100$ & $\begin{array}{c}0.0143 \\
(0.1439)\end{array}$ & $\begin{array}{c}3.2797 * * * \\
(0.3724)\end{array}$ & $\begin{array}{c}2.0128 * * \\
(0.8123)\end{array}$ \\
\hline$\Delta O S S_{i t} / 100$ & $\begin{array}{c}0.1114 \\
(0.1681)\end{array}$ & $\begin{array}{c}-1.6064 * * * \\
(0.4031)\end{array}$ & $\begin{array}{c}-2.0121 * * * \\
(0.7099)\end{array}$ \\
\hline OSM $_{i t} / 100$ & $\begin{array}{c}-0.0407 * * \\
(0.0200)\end{array}$ & $\begin{array}{c}-0.4829 * * * \\
(0.1095)\end{array}$ & $\begin{array}{l}-0.2388 * \\
(0.1353)\end{array}$ \\
\hline$\Delta \mathrm{OSM}_{i t} / 100$ & $\begin{array}{c}-0.1064 * \\
(0.0569)\end{array}$ & $\begin{array}{c}-1.4215 * * * \\
(0.2047)\end{array}$ & $\begin{array}{c}-0.3095 \\
(0.3168)\end{array}$ \\
\hline $\ln Y_{i t}$ & $\begin{array}{c}0.0321 * * * \\
(0.0053)\end{array}$ & $\begin{array}{c}0.0594 * * \\
(0.0255)\end{array}$ & $\begin{array}{c}0.0236 \\
(0.0239)\end{array}$ \\
\hline$\Delta \ln Y_{i t}$ & $\begin{array}{c}0.1215^{* * * *} \\
(0.0093)\end{array}$ & $\begin{array}{c}0.0277 \\
(0.0268)\end{array}$ & $\begin{array}{c}0.1502 * * * \\
(0.0273)\end{array}$ \\
\hline
\end{tabular}

Joint tests (Wald):

\begin{tabular}{|c|c|c|c|}
\hline $\ln L_{i t-1}=1$ & $\begin{array}{c}\chi^{2}(1)=77.80 \\
p \text {-value }=0.0000\end{array}$ & $\begin{array}{c}\chi^{2}(1)=31.35 \\
p \text {-value }=0.0000\end{array}$ & $\begin{array}{c}\chi^{2}(1)=21.74 \\
p \text {-value }=0.0000\end{array}$ \\
\hline $\ln w_{i t}+\ln w_{i t-1}=0$ & $\begin{array}{c}\chi^{2}(1)=67.20 \\
p \text {-value }=0.0000\end{array}$ & $\begin{array}{c}\chi^{2}(1)=20.95 \\
p \text {-value }=0.0000\end{array}$ & $\begin{array}{c}\chi^{2}(1)=17.75 \\
p \text {-value }=0.0000\end{array}$ \\
\hline$O S S_{i t}+O S S_{i t-1}=0$ & $\begin{aligned} \chi^{2}(1) & =0.01 \\
p \text {-value } & =0.9204\end{aligned}$ & $\begin{array}{c}\chi^{2}(1)=77.53 \\
p \text {-value }=0.0000\end{array}$ & $\begin{aligned} \chi^{2}(1) & =6.13 \\
p \text {-value } & =0.0132\end{aligned}$ \\
\hline$O S M_{i t}+O S M_{i t-1}=0$ & $\begin{aligned} \chi^{2}(1) & =4.13 \\
p-\text { value } & =0.0421\end{aligned}$ & $\begin{array}{c}\chi^{2}(1)=19.45 \\
p \text {-value }=0.0000\end{array}$ & $\begin{aligned} \chi^{2}(1) & =3.11 \\
p-\text { value } & =0.0775\end{aligned}$ \\
\hline $\ln Y_{i t}+\ln Y_{i t-1}=0$ & $\begin{array}{c}\chi^{2}(1)=36.54 \\
\text {-value }=0.0000\end{array}$ & $\begin{aligned} \chi^{2}(1) & =5.41 \\
p \text {-value } & =0.0200\end{aligned}$ & $\begin{array}{c}\chi^{2}(1)=0.97 \\
p \text {-value }=0.3235\end{array}$ \\
\hline Sargan test: & - & $\begin{aligned} \chi^{2}(37) & =60.14 \\
p-\text { value } & =0.0094\end{aligned}$ & $\begin{aligned} \chi^{2}(37) & =44.70 \\
p-\text { value } & =0.1797\end{aligned}$ \\
\hline m2 test: & - & $\begin{array}{c}\mathrm{z}=1.64 \\
p \text {-value }=0.1010\end{array}$ & $\begin{array}{c}\mathrm{z}=2.01 \\
p \text {-value }=0.0441\end{array}$ \\
\hline Period dummies & yes & no & yes \\
\hline s.e. & 0.0359 & 0.0439 & 0.0386 \\
\hline Adj. $\mathbf{r}^{2}$ & 0.9999 & 0.9431 & 0.9561 \\
\hline observations & 2075 & 1743 & 1743 \\
\hline
\end{tabular}

Note: all three estimations based on equation (8) above. FE is the fixed effects estimator (both year and industry dummies); while GMM is the Arellano-Bover (1995) estimator in orthogonal deviations with and without period fixed effects. Standard errors in parentheses and ${ }^{*},{ }^{* *},{ }^{* *}$ stand for the usual levels of significances, $10 \%, 5 \%$, and $1 \%$. The Sargan test is a test for the validity of the instruments whereas the $\mathrm{m} 2$ test is the test for second-order autocorrelation in the errors by ArellanoBond (1991). 
Table A10: Unconditional Labor Demand

Whole economy (83 industries)

Dependent variable: $\ln L_{i t}$

\begin{tabular}{|c|c|c|c|}
\hline & FE & GMM & GMM \\
\hline \multirow{2}{*}{$\ln L_{i t-1}$} & $0.9717 * * *$ & $0.9226 * * *$ & $0.8881 * * *$ \\
\hline & $(0.0037)$ & $(0.0083)$ & $(0.0095)$ \\
\hline \multirow[t]{2}{*}{$\ln w_{i t}$} & $-0.0137 * * *$ & $-0.0524 * * *$ & $-0.1244 * * *$ \\
\hline & $(0.0035)$ & $(0.0134)$ & $(0.0183)$ \\
\hline \multirow[t]{2}{*}{$\Delta \ln w_{i t}$} & $-0.0324 * * *$ & $-0.0527 * * *$ & $-0.0552 * *$ \\
\hline & $(0.0078)$ & $(0.0194)$ & $(0.0223)$ \\
\hline \multirow{2}{*}{$O S S_{i t} / 100$} & 0.0099 & $3.4532 * * *$ & $4.5562 * * *$ \\
\hline & $(0.1251)$ & $(0.3159)$ & $(1.0065)$ \\
\hline \multirow[t]{2}{*}{$\Delta O S S_{i t} / 100$} & 0.1671 & $-0.8303^{*}$ & $-2.9746 * * *$ \\
\hline & $(0.1716)$ & $(0.4658)$ & $(0.8015)$ \\
\hline \multirow[t]{2}{*}{$O S M_{i t} / 100$} & $-0.1856 * * *$ & $-0.5552 * * *$ & $-0.4695 * * *$ \\
\hline & $(0.0206)$ & $(0.1118)$ & $(0.1244)$ \\
\hline \multirow[t]{2}{*}{$\Delta$ OSM $_{i t} / 100$} & $-0.3578 * * *$ & $-0.9849 * * *$ & $-0.5098 *$ \\
\hline & $(0.0755)$ & $(0.1960)$ & $(0.2704)$ \\
\hline \multirow[t]{2}{*}{$\ln p_{i t}^{Y}$} & $0.0302 * * *$ & $0.0329 * * *$ & $-0.0356 * *$ \\
\hline & $(0.0046)$ & $(0.0115)$ & $(0.0147)$ \\
\hline \multirow[t]{2}{*}{$\Delta \ln p_{i t}^{Y}$} & $0.0532 * * *$ & $0.1435 * * *$ & $0.1111 * * *$ \\
\hline & $(0.0148)$ & $(0.0206)$ & $(0.0311)$ \\
\hline
\end{tabular}

Joint tests (Wald):

\begin{tabular}{|c|c|c|c|}
\hline $\ln L_{i t-1}=1$ & $\begin{array}{c}\chi^{2}(1)=57.33 \\
p \text {-value }=0.0000\end{array}$ & $\begin{array}{c}\chi^{2}(1)=86.24 \\
\text {-value }=0.0000\end{array}$ & $\begin{array}{c}\chi^{2}(1)=135.95 \\
p \text {-value }=0.0000\end{array}$ \\
\hline $\ln w_{i t}+\ln w_{i t-1}=0$ & $\begin{array}{c}\chi^{2}(1)=14.91 \\
p \text {-value }=0.0001\end{array}$ & $\begin{array}{c}\chi^{2}(1)=15.23 \\
p \text {-value }=0.0001\end{array}$ & $\begin{array}{c}\chi^{2}(1)=46.06 \\
p \text {-value }=0.0000\end{array}$ \\
\hline$O S S_{i t}+O S S_{i t-1}=0$ & $\begin{array}{c}\chi^{2}(1)=0.006 \\
p \text {-value }=0.9364\end{array}$ & $\begin{array}{c}\chi^{2}(1)=119.46 \\
p \text {-value }=0.0000\end{array}$ & $\begin{array}{c}\chi^{2}(1)=20.49 \\
p \text {-value }=0.0000\end{array}$ \\
\hline$O S M_{i t}+O S M_{i t-1}=0$ & $\begin{array}{c}\chi^{2}(1)=80.88 \\
p \text {-value }=0.0000\end{array}$ & $\begin{array}{c}\chi^{2}(1)=24.62 \\
p \text {-value }=0.0000\end{array}$ & $\begin{array}{c}\chi^{2}(1)=14.23 \\
p \text {-value }=0.0002\end{array}$ \\
\hline $\ln p_{i t}^{Y}+\ln p_{i t-1}^{Y}=0$ & $\begin{array}{c}\chi^{2}(1)=41.78 \\
\text { p-value }=0.0000\end{array}$ & $\begin{array}{c}\chi^{2}(1)=8.13 \\
p \text {-value }=0.0043\end{array}$ & $\begin{array}{c}\chi^{2}(1)=5.81 \\
p \text {-value }=0.0159\end{array}$ \\
\hline Sargan test: & - & $\begin{aligned} \chi^{2}(37) & =57.19 \\
p \text {-value } & =0.0181\end{aligned}$ & $\begin{aligned} \chi^{2}(37) & =41.80 \\
p \text {-value } & =0.2698\end{aligned}$ \\
\hline m2 test: & - & $\begin{array}{c}\mathrm{z}=0.03 \\
p \text {-value }=0.4916\end{array}$ & $\begin{array}{c}\mathrm{z}=-4.66 \\
p \text {-value }=0.0000\end{array}$ \\
\hline Period dummies & no & no & yes \\
\hline s.e. & 0.0395 & & \\
\hline $\begin{array}{l}\text { Adj. } \mathbf{r}^{2} \\
\text { observations }\end{array}$ & $\begin{array}{c}0.9999 \\
2075\end{array}$ & 1743 & 1743 \\
\hline
\end{tabular}

Note: all three estimations based on Equation (8') above. 
Table A11: Conditional Labor Demand (Hours Worked)

Whole economy (83 industries)

Dependent variable: $\ln \boldsymbol{H}_{i t}$

\begin{tabular}{|c|c|c|c|}
\hline & FE & GMM & GMM \\
\hline \multirow[t]{2}{*}{$\ln H_{i t-1}$} & $0.9369 * * *$ & $0.9209 * * *$ & $0.8258 * * *$ \\
\hline & $(0.0064)$ & $(0.0187)$ & $(0.0215)$ \\
\hline \multirow[t]{2}{*}{$\ln w_{i t}$} & $-0.0451 * * *$ & $-0.0642 * * *$ & $-0.1161 * * *$ \\
\hline & $(0.0059)$ & $(0.0247)$ & $(0.0208)$ \\
\hline \multirow[t]{2}{*}{$\Delta \ln w_{i t}$} & $-0.1303 * * *$ & $-0.1152 * * *$ & $-0.1066 * * *$ \\
\hline & (0.0104) & $(0.0287)$ & $(0.0199)$ \\
\hline \multirow{2}{*}{$O S S_{i t} / 100$} & 0.2367 & $1.7897 * * *$ & $0.9777 * *$ \\
\hline & $(0.1664)$ & $(0.3540)$ & $(0.4678)$ \\
\hline \multirow[t]{2}{*}{$\Delta \mathrm{OSS}_{i t} / 100$} & -0.0836 & -0.0283 & -0.5473 \\
\hline & $(0.2062)$ & $(0.4295)$ & $(0.4445)$ \\
\hline \multirow[t]{2}{*}{$O S M_{i t} / 100$} & $-0.0470 * *$ & $-0.2219 *$ & $-0.3189 * *$ \\
\hline & (0.0208) & (0.1138) & $(0.1466)$ \\
\hline \multirow[t]{2}{*}{$\Delta \mathrm{OSM}_{i t} / 100$} & $-0.1515^{* *}$ & $-1.4135 * * *$ & -0.3095 \\
\hline & (0.0590) & $(0.2537)$ & $(0.2526)$ \\
\hline \multirow{2}{*}{$\ln Y_{i t}$} & $0.0352 * * *$ & -0.0048 & $0.0961 * * *$ \\
\hline & $(0.0057)$ & $(0.0191)$ & $(0.0227)$ \\
\hline \multirow[t]{2}{*}{$\Delta \ln Y_{i t}$} & $0.1256 * * *$ & $0.2918 * * *$ & $0.0963 * * *$ \\
\hline & $(0.0100)$ & (0.0308) & (0.0306) \\
\hline
\end{tabular}

Joint tests (Wald):

\begin{tabular}{|c|c|c|c|}
\hline $\ln H_{i t-1}=1$ & $\begin{array}{c}\chi^{2}(1)=95.24 \\
p \text {-value }=0.0000\end{array}$ & $\begin{array}{c}\chi^{2}(1)=17.83 \\
p \text {-value }=0.0000\end{array}$ & $\begin{array}{c}\chi^{2}(1)=65.62 \\
\text {-value }=0.0000\end{array}$ \\
\hline $\ln w_{i t}+\ln w_{i t-1}=0$ & $\begin{array}{c}\chi^{2}(1)=57.00 \\
p \text {-value }=0.0000\end{array}$ & $\begin{aligned} \chi^{2}(1) & =6.70 \\
p-\text { value } & =0.0096\end{aligned}$ & $\begin{array}{c}\chi^{2}(1)=30.90 \\
p \text {-value }=0.0000\end{array}$ \\
\hline$O S S_{i t}+O S S_{i t-1}=0$ & $\begin{aligned} \chi^{2}(1) & =2.02 \\
p \text {-value } & =0.1550\end{aligned}$ & $\begin{array}{c}\chi^{2}(1)=25.55 \\
p \text {-value }=0.0000\end{array}$ & $\begin{aligned} \chi^{2}(1) & =4.36 \\
p \text {-value } & =0.0366\end{aligned}$ \\
\hline$O S M_{i t}+O S M_{i t-1}=0$ & $\begin{aligned} \chi^{2}(1) & =5.06 \\
p \text {-value } & =0.0244\end{aligned}$ & $\begin{aligned} \chi^{2}(1) & =3.80 \\
p \text {-value } & =0.0512\end{aligned}$ & $\begin{aligned} \chi^{2}(1) & =4.72 \\
p \text {-value } & =0.0297\end{aligned}$ \\
\hline $\ln Y_{i t}+\ln Y_{i t-1}=0$ & $\begin{array}{c}\chi^{2}(1)=37.16 \\
p \text {-value }=0.0000\end{array}$ & $\begin{aligned} \chi^{2}(1) & =0.06 \\
p \text {-value } & =0.8005\end{aligned}$ & $\begin{array}{c}\chi^{2}(1)=17.79 \\
p \text {-value }=0.0000\end{array}$ \\
\hline Sargan test: & - & $\begin{array}{c}\chi^{2}(37)=65.12 \\
p \text {-value }=0.0029\end{array}$ & $\begin{aligned} \chi^{2}(37) & =51.16 \\
p-\text { value } & =0.0606\end{aligned}$ \\
\hline m2 test: & - & $\begin{array}{c}\mathrm{z}=4.23 \\
\text {-value }=0.0000\end{array}$ & $\begin{array}{c}\mathrm{z}=2.20 \\
\text { p-value }=0.0273\end{array}$ \\
\hline Period dummies & yes & no & yes \\
\hline s.e. & 0.0380 & 0.0456 & 0.0396 \\
\hline Adj. $\mathbf{r}^{2}$ & 0.9999 & 0.9360 & 0.9517 \\
\hline observations & 2075 & 1743 & 1743 \\
\hline
\end{tabular}

Note: all three estimations based on Equation (8) above.

Dependent variable is man-hours by industry (1000 workers $\times$ total annual working hours). 
Table A12: Unconditional Labor Demand (Hours Worked)

Whole economy (83 industries)

Dependent variable: $\ln \boldsymbol{H}_{i t}$

\begin{tabular}{|c|c|c|c|}
\hline & FE & GMM & GMM \\
\hline $\ln H_{i t-1}$ & $\begin{array}{c}0.9688 * * * \\
(0.0042)\end{array}$ & $\begin{array}{c}0.9081 * * * \\
(0.0092)\end{array}$ & $\begin{array}{c}0.8826 * * * \\
(0.0103)\end{array}$ \\
\hline $\ln w_{i t}$ & $\begin{array}{c}-0.0221 * * * \\
(0.0042)\end{array}$ & $\begin{array}{c}-0.0695 * * * \\
(0.0123)\end{array}$ & $\begin{array}{c}-0.1054 * * * \\
(0.0159)\end{array}$ \\
\hline$\Delta \ln w_{i t}$ & $\begin{array}{c}-0.0251 * * * \\
(0.0087)\end{array}$ & $\begin{array}{l}0.0424 * \\
(0.0246)\end{array}$ & $\begin{array}{c}-0.0893 * * * \\
(0.0225)\end{array}$ \\
\hline$O S S_{i t} / 100$ & $\begin{array}{c}-0.4672 * * * \\
(0.1447)\end{array}$ & $\begin{array}{c}2.2719 * * * \\
(0.3477)\end{array}$ & $\begin{array}{c}4.2606 * * * \\
(0.8732)\end{array}$ \\
\hline$\Delta O^{\prime} S_{i t} / 100$ & $\begin{array}{c}0.5034 * * \\
(0.2070)\end{array}$ & $\begin{array}{c}1.2611 * * \\
(0.6155)\end{array}$ & $\begin{array}{c}-1.4044 * * \\
(0.5485)\end{array}$ \\
\hline OSM $_{i t} / 100$ & $\begin{array}{c}-0.1947 * * * \\
(0.0243)\end{array}$ & $\begin{array}{c}-0.5067 * * * \\
(0.1106)\end{array}$ & $\begin{array}{c}-0.4395 * * * \\
(0.1358)\end{array}$ \\
\hline$\Delta O^{\prime} M_{i t} / 100$ & $\begin{array}{c}-0.4253 * * * \\
(0.0835)\end{array}$ & $\begin{array}{c}-1.9228 * * * \\
(0.2719)\end{array}$ & $\begin{array}{c}-0.5658^{*} \\
(0.3181)\end{array}$ \\
\hline $\ln p_{i t}^{Y}$ & $\begin{array}{c}0.0173 * * * \\
(0.0051)\end{array}$ & $\begin{array}{l}0.0192 * \\
(0.0110)\end{array}$ & $\begin{array}{c}-0.0295^{* *} * \\
(0.0144)\end{array}$ \\
\hline$\Delta \ln p_{i t}^{Y}$ & $\begin{array}{c}0.0443 * * * \\
(0.0160)\end{array}$ & $\begin{array}{l}0.0497 * \\
(0.0265)\end{array}$ & $\begin{array}{c}0.1365 * * * \\
(0.0337)\end{array}$ \\
\hline
\end{tabular}

Joint tests (Wald):

\begin{tabular}{|c|c|c|c|}
\hline $\ln H_{i t-1}=1$ & $\begin{array}{c}\chi^{2}(1)=53.38 \\
\text {-value }=0.0000\end{array}$ & $\begin{array}{c}\chi^{2}(1)=97.61 \\
p \text {-value }=0.0000\end{array}$ & $\begin{array}{c}\chi^{2}(1)=128.77 \\
p \text {-value }=0.0000\end{array}$ \\
\hline $\ln w_{i t}+\ln w_{i t-1}=0$ & $\begin{array}{c}\chi^{2}(1)=27.71 \\
p \text {-value }=0.0040\end{array}$ & $\begin{array}{c}\chi^{2}(1)=31.65 \\
p \text {-value }=0.0000\end{array}$ & $\begin{array}{c}\chi^{2}(1)=43.91 \\
p \text {-value }=0.0000\end{array}$ \\
\hline$O S S_{i t}+O S S_{i t-1}=0$ & $\begin{array}{c}\chi^{2}(1)=10.41 \\
\text {-value }=0.0012\end{array}$ & $\begin{array}{c}\chi^{2}(1)=42.69 \\
p \text {-value }=0.0000\end{array}$ & $\begin{array}{c}\chi^{2}(1)=23.80 \\
p \text {-value }=0.0000\end{array}$ \\
\hline$O S M_{i t}+O S M_{i t-1}=0$ & $\begin{array}{c}\chi^{2}(1)=64.03 \\
p \text {-value }=0.0000\end{array}$ & $\begin{array}{c}\chi^{2}(1)=20.95 \\
p \text {-value }=0.0000\end{array}$ & $\begin{array}{c}\chi^{2}(1)=10.46 \\
p \text {-value }=0.0012\end{array}$ \\
\hline $\ln p_{i t}^{Y}+\ln p_{i t-1}^{Y}=0$ & $\begin{array}{c}\chi^{2}(1)=11.49 \\
p \text {-value }=0.0007\end{array}$ & $\begin{aligned} \chi^{2}(1) & =3.00 \\
p \text {-value } & =0.0830\end{aligned}$ & $\begin{array}{c}\chi^{2}(1)=4.15 \\
p \text {-value }=0.0415\end{array}$ \\
\hline Sargan test: & - & $\begin{aligned} \chi^{2}(37) & =71.70 \\
p \text {-value } & =0.0005\end{aligned}$ & $\begin{aligned} \chi^{2}(37) & =43.95 \\
p \text {-value } & =0.2007\end{aligned}$ \\
\hline m2 test: & - & $\begin{array}{c}\mathrm{z}=-1.32 \\
p \text {-value }=0.1841\end{array}$ & $\begin{array}{c}\mathrm{z}=-4.69 \\
p \text {-value }=0.0000\end{array}$ \\
\hline Period dummies & no & no & yes \\
\hline s.e. & 0.0424 & 0.0498 & 0.0476 \\
\hline Adj. $\mathbf{r}^{2}$ & 0.9999 & 0.9234 & 0.9300 \\
\hline observations & 2075 & 1743 & 1743 \\
\hline
\end{tabular}

Note: all three estimations based on equation (8') above.

Dependent variable is man-hours by industry (1000 workers $\times$ total annual working hours). 
Table A13: Conditional Labor Demand

Manufacturing activities (48 industries)

Dependent variable: $\ln L_{i t}$

\begin{tabular}{|c|c|c|c|}
\hline & FE & FE & GMM \\
\hline $\ln L_{i t-1}$ & $\begin{array}{c}0.8936 * * * \\
(0.0108)\end{array}$ & $\begin{array}{c}0.8926 * * * \\
(0.0106)\end{array}$ & $\begin{array}{c}0.8868 * * * \\
(0.0155)\end{array}$ \\
\hline $\ln w_{i t}$ & $\begin{array}{c}-0.1036 * * * \\
(0.0096)\end{array}$ & $\begin{array}{c}-0.0541 * * * \\
(0.0095)\end{array}$ & $\begin{array}{c}-0.0947 * * * * \\
(0.0157)\end{array}$ \\
\hline$\Delta \ln w_{i t}$ & $\begin{array}{c}-0.1262 * * * \\
(0.0138)\end{array}$ & $\begin{array}{c}-0.1214 * * * \\
(0.0132)\end{array}$ & $\begin{array}{c}-0.1330 * * * * \\
(0.0147)\end{array}$ \\
\hline$O S S_{i t} / 100$ & $\begin{array}{c}1.3631 * * * \\
(0.2544)\end{array}$ & $\begin{array}{c}1.1231 * * * \\
(0.3261)\end{array}$ & $\begin{array}{c}3.6146 * * * * \\
(0.3356)\end{array}$ \\
\hline$\Delta O_{S S} S_{i t} / 100$ & $\begin{array}{c}-1.0693 * * \\
(0.5241)\end{array}$ & $\begin{array}{l}-0.6435 \\
(0.8116)\end{array}$ & $\begin{array}{c}-3.5713 * * * * \\
(0.3015)\end{array}$ \\
\hline $\mathrm{OSM}_{i t} / 100$ & $\begin{array}{c}-0.1132 \text { *** } \\
(0.0240)\end{array}$ & $\begin{array}{c}-0.0308 \\
(0.0212)\end{array}$ & $\begin{array}{c}-0.4182 \text { **** } \\
(0.0518)\end{array}$ \\
\hline$\Delta O S M_{i t} / 100$ & $\begin{array}{c}-0.1832 * * * \\
(0.0695)\end{array}$ & $\begin{array}{c}-0.0798 \\
(0.0583)\end{array}$ & $\begin{array}{c}-1.4484 * * * * \\
(0.1279)\end{array}$ \\
\hline $\ln Y_{i t}$ & $\begin{array}{c}0.0654 * * * \\
(0.0099)\end{array}$ & $\begin{array}{c}0.0408 * * * \\
(0.0095)\end{array}$ & $\begin{array}{c}0.0324 * * \\
(0.0158)\end{array}$ \\
\hline$\Delta \ln Y_{i t}$ & $\begin{array}{c}0.1467 * * * \\
(0.0129)\end{array}$ & $\begin{array}{c}0.1161 * * * \\
(0.0126)\end{array}$ & $\begin{array}{c}0.1040 * * * \\
(0.0177)\end{array}$ \\
\hline
\end{tabular}

Joint tests (Wald):

\begin{tabular}{|c|c|c|c|}
\hline $\ln L_{i t-1}=1$ & $\begin{array}{c}\chi^{2}(1)=96.82 \\
p \text {-value }=0.0000\end{array}$ & $\begin{array}{c}\chi^{2}(1)=101.52 \\
p \text {-value }=0.0000\end{array}$ & $\begin{array}{c}\chi^{2}(1)=52.90 \\
p \text {-value }=0.0000\end{array}$ \\
\hline $\ln w_{i t}+\ln w_{i t-1}=0$ & $\begin{array}{c}\chi^{2}(1)=115.92 \\
p \text {-value }=0.0000\end{array}$ & $\begin{array}{c}\chi^{2}(1)=31.89 \\
p \text {-value }=0.0000\end{array}$ & $\begin{array}{c}\chi^{2}(1)=36.27 \\
\text { p-value }=0.0000\end{array}$ \\
\hline$O S S_{i t}+O S S_{i t-1}=0$ & $\begin{array}{c}\chi^{2}(1)=28.70 \\
p \text {-value }=0.0000\end{array}$ & $\begin{array}{c}\chi^{2}(1)=11.85 \\
p \text {-value }=0.0006\end{array}$ & $\begin{array}{c}\chi^{2}(1)=115.98 \\
p \text {-value }=0.0000\end{array}$ \\
\hline$O S M_{i t}+O S M_{i t-1}=0$ & $\begin{array}{c}\chi^{2}(1)=22.24 \\
p \text {-value }=0.0000\end{array}$ & $\begin{aligned} \chi^{2}(1) & =2.11 \\
p \text {-value } & =0.1460\end{aligned}$ & $\begin{array}{c}\chi^{2}(1)=65.04 \\
\text { p-value }=0.0000\end{array}$ \\
\hline $\ln Y_{i t}+\ln Y_{i t-1}=0$ & $\begin{array}{c}\chi^{2}(1)=43.22 \\
p \text {-value }=0.0000\end{array}$ & $\begin{array}{c}\chi^{2}(1)=18.36 \\
p \text {-value }=0.0000\end{array}$ & $\begin{aligned} \chi^{2}(1) & =4.17 \\
p \text {-value } & =0.0411\end{aligned}$ \\
\hline
\end{tabular}

$\begin{array}{lccc}\text { Sargan test: } & - & - & \chi^{2}(37)=46.18 \\ \text { m2 test: } & - & - & \text {-value }=0.1430 \\ & & & \mathrm{z}=1.27 \\ \text { P-value }=0.2037\end{array}$

Note: estimations based on equation (8) above for manufacturing activities only (see table A2). 
Table A14: Unconditional Labor Demand

Manufacturing activities (48 industries)

Dependent variable: $\ln L_{i t}$

\begin{tabular}{|c|c|c|c|}
\hline & $\overline{F E}$ & FE & GMM \\
\hline $\ln L_{i t-1}$ & $\begin{array}{c}0.9383 * * * \\
(0.0073)\end{array}$ & $\begin{array}{c}0.9232 * * * \\
(0.0072)\end{array}$ & $\begin{array}{c}0.9321 * * * \\
(0.0059)\end{array}$ \\
\hline $\ln w_{i t}$ & $\begin{array}{c}-0.0520 * * * \\
(0.0061)\end{array}$ & $\begin{array}{c}0.0044 \\
(0.0073)\end{array}$ & $\begin{array}{c}-0.0525 * * * \\
(0.0056)\end{array}$ \\
\hline$\Delta \ln w_{i t}$ & $\begin{array}{c}-0.0143 \\
(0.0106)\end{array}$ & $\begin{array}{c}-0.0489 * * * \\
(0.0102)\end{array}$ & $\begin{array}{c}-0.0565 * * * \\
(0.0101)\end{array}$ \\
\hline$O S S_{i t} / 100$ & $\begin{array}{c}1.8623 * * * \\
(0.2763)\end{array}$ & $\begin{array}{c}1.0679 * * * \\
(0.3304)\end{array}$ & $\begin{array}{c}3.8727 * * * \\
(0.2063)\end{array}$ \\
\hline$\Delta \mathrm{OSS}_{i t} / 100$ & $\begin{array}{c}-0.8799 \\
(0.5980)\end{array}$ & $\begin{array}{c}-0.3949 \\
(0.8140)\end{array}$ & $\begin{array}{c}-2.4526 * * * \\
(0.4806)\end{array}$ \\
\hline OSM $_{i t} / 100$ & $\begin{array}{c}-0.1856 * * * \\
(0.0283)\end{array}$ & $\begin{array}{c}-0.0544 * * \\
(0.0229)\end{array}$ & $\begin{array}{c}-0.5134 * * * \\
(0.0544)\end{array}$ \\
\hline$\Delta \mathrm{OSM}_{i t} / 100$ & $\begin{array}{c}-0.3730 * * * \\
(0.0846)\end{array}$ & $\begin{array}{c}-0.1491 * * \\
(0.0644)\end{array}$ & $\begin{array}{c}-1.6666^{* * *} * \\
(0.1365)\end{array}$ \\
\hline $\ln p_{i t}^{Y}$ & $\begin{array}{c}0.0068 \\
(0.0070)\end{array}$ & $\begin{array}{c}0.0321 * * * \\
(0.0066)\end{array}$ & $\begin{array}{c}0.0340 * * * \\
(0.0071)\end{array}$ \\
\hline$\Delta \ln p_{i t}^{Y}$ & $\begin{array}{c}0.0867 * * * \\
(0.0194)\end{array}$ & $\begin{array}{l}0.0304 * \\
(0.0172)\end{array}$ & $\begin{array}{c}0.1315 * * * \\
(0.0116)\end{array}$ \\
\hline
\end{tabular}

Joint tests (Wald):

\begin{tabular}{|c|c|c|c|}
\hline $\ln L_{i t-1}=1$ & $\begin{array}{c}\chi^{2}(1)=70.68 \\
\text {-value }=0.0000\end{array}$ & $\begin{array}{c}\chi^{2}(1)=113.53 \\
p \text {-value }=0.0000\end{array}$ & $\begin{array}{c}\chi^{2}(1)=130.58 \\
\text {-value }=0.0000\end{array}$ \\
\hline $\ln w_{i t}+\ln w_{i t-1}=0$ & $\begin{array}{c}\chi^{2}(1)=72.31 \\
\text {-value }=0.0000\end{array}$ & $\begin{array}{c}\chi^{2}(1)=0.35 \\
p \text {-value }=0.5488\end{array}$ & $\begin{array}{c}\chi^{2}(1)=86.26 \\
p \text {-value }=0.0000\end{array}$ \\
\hline$O S S_{i t}+O S S_{i t-1}=0$ & $\begin{array}{c}\chi^{2}(1)=45.42 \\
\text { p-value }=0.0000\end{array}$ & $\begin{array}{c}\chi^{2}(1)=10.44 \\
p \text {-value }=0.0012\end{array}$ & $\begin{array}{c}\chi^{2}(1)=352.17 \\
p \text {-value }=0.0000\end{array}$ \\
\hline$O S M_{i t}+O S M_{i t-1}=0$ & $\begin{array}{c}\chi^{2}(1)=42.78 \\
\text {-value }=0.0000\end{array}$ & $\begin{aligned} \chi^{2}(1) & =5.63 \\
p \text {-value } & =0.0176\end{aligned}$ & $\begin{array}{c}\chi^{2}(1)=88.88 \\
\text { p-value }=0.0000\end{array}$ \\
\hline $\ln p_{i t}^{Y}+\ln p_{i t-1}^{Y}=0$ & $\begin{array}{c}\chi^{2}(1)=0.95 \\
\text { p-value }=0.3277\end{array}$ & $\begin{array}{c}\chi^{2}(1)=23.20 \\
p \text {-value }=0.0000\end{array}$ & $\begin{array}{c}\chi^{2}(1)=22.80 \\
p \text {-value }=0.0000\end{array}$ \\
\hline
\end{tabular}

\begin{tabular}{lccc} 
Sargan test: & - & - & $\chi^{2}(37)=46.08$ \\
& & & $p$-value $=0.1453$ \\
m2 test: & - & - & $\mathrm{z}=1.24$ \\
& & & p-value $=0.2125$ \\
Period dummies & no & yes & no \\
S.e. & 0.0438 & 0.0403 & 0.0482 \\
Adj. $\mathbf{r}^{2}$ & 0.9999 & 0.9999 & 0.8927 \\
observations & 1200 & 1200 & 1008 \\
\hline
\end{tabular}

Note: estimations based on Equation (8') above for manufacturing activities only (see Table A2). 
Table A15: Conditional Labor Demand

Services activities (27 industries)

Dependent variable: $\ln L_{i t}$

\begin{tabular}{|c|c|c|}
\hline & FE & FE \\
\hline $\ln L_{i t-1}$ & $\begin{array}{c}0.9643 * * * \\
(0.0079)\end{array}$ & $\begin{array}{c}0.9617 * * * \\
(0.0076)\end{array}$ \\
\hline $\ln w_{i t}$ & $\begin{array}{c}-0.0216 * * * \\
(0.0078)\end{array}$ & $\begin{array}{c}-0.0255^{* * *} * \\
(0.0073)\end{array}$ \\
\hline$\Delta \ln w_{i t}$ & $\begin{array}{c}-0.1090 * * * \\
(0.0156)\end{array}$ & $\begin{array}{c}-0.1161 * * * \\
(0.0154)\end{array}$ \\
\hline$O S S_{i t} / 100$ & $\begin{array}{c}-0.3304 * * \\
(0.1370)\end{array}$ & $\begin{array}{c}-0.4542 * * * \\
(0.1600)\end{array}$ \\
\hline$\Delta O S S_{i t} / 100$ & $\begin{array}{c}0.3269 * * \\
(0.1481)\end{array}$ & $\begin{array}{c}0.3996 * * \\
(0.1553)\end{array}$ \\
\hline $\mathrm{OSM}_{i t} / 100$ & $\begin{array}{l}-0.0932 \\
(0.0592)\end{array}$ & $\begin{array}{c}0.0840 \\
(0.0913)\end{array}$ \\
\hline$\Delta \mathrm{OSM}_{i t} / 100$ & $\begin{array}{c}-0.8704 * * * \\
(0.2452)\end{array}$ & $\begin{array}{c}-1.0423 * * * \\
(0.2806)\end{array}$ \\
\hline $\ln Y_{i t}$ & $\begin{array}{c}0.0157 * * \\
(0.0074)\end{array}$ & $\begin{array}{c}0.0163 * * \\
(0.0070)\end{array}$ \\
\hline$\Delta \ln Y_{i t}$ & $\begin{array}{c}0.0902 * * * \\
(0.0158)\end{array}$ & $\begin{array}{c}0.1007 * * * \\
(0.0152)\end{array}$ \\
\hline
\end{tabular}

Joint tests (Wald):

\begin{tabular}{|c|c|c|}
\hline $\ln L_{i t-1}=1$ & $\begin{array}{c}\chi^{2}(1)=20.30 \\
\text {-value }=0.0000\end{array}$ & $\begin{array}{c}\chi^{2}(1)=24.93 \\
p \text {-value }=0.0000\end{array}$ \\
\hline $\ln w_{i t}+\ln w_{i t-1}=0$ & $\begin{aligned} \chi^{2}(1) & =7.56 \\
p \text {-value } & =0.0059\end{aligned}$ & $\begin{array}{c}\chi^{2}(1)=11.97 \\
p \text {-value }=0.0005\end{array}$ \\
\hline$O S S_{i t}+O S S_{i t-1}=0$ & $\begin{aligned} \chi^{2}(1) & =5.81 \\
p \text {-value } & =0.0159\end{aligned}$ & $\begin{array}{c}\chi^{2}(1)=8.05 \\
p \text {-value }=0.0045\end{array}$ \\
\hline$O S M_{i t}+O S M_{i t-1}=0$ & $\begin{aligned} \chi^{2}(1) & =2.47 \\
p \text {-value } & =0.1156\end{aligned}$ & $\begin{array}{c}\chi^{2}(1)=0.84 \\
p \text {-value }=0.3572\end{array}$ \\
\hline $\ln Y_{i t}+\ln Y_{i t-1}=0$ & $\begin{array}{c}\chi^{2}(1)=4.51 \\
p \text {-value }=0.0336\end{array}$ & $\begin{array}{c}\chi^{2}(1)=5.34 \\
p \text {-value }=0.0208\end{array}$ \\
\hline
\end{tabular}

\begin{tabular}{lcc} 
Period dummies & No & Yes \\
s.e. & 0.0256 & 0.0247 \\
Adj. $\mathbf{r}^{2}$ & 0.9999 & 0.9999 \\
observations & 675 & 675 \\
\hline
\end{tabular}

Note: estimations based on Equation (8) above for services activities only (see Table A2). 
Table A16: Labor demand (no output variables)

Whole economy (83 industries)

Dependent variable: $\ln L_{i t}$

\begin{tabular}{|c|c|c|}
\hline & GMM & GMM \\
\hline $\ln L_{i t-1}$ & $\begin{array}{c}0.9238 * * * \\
(0.0118)\end{array}$ & $\begin{array}{c}0.9016 * * * \\
(0.0186)\end{array}$ \\
\hline $\ln w_{i t}$ & $\begin{array}{c}-0.0767 * * * \\
(0.0148)\end{array}$ & $\begin{array}{c}-0.0780 * * * * \\
(0.0215)\end{array}$ \\
\hline$\Delta \ln w_{i t}$ & $\begin{array}{c}-0.0604 * * * \\
(0.0194)\end{array}$ & $\begin{array}{c}-0.0527 * * \\
(0.0212)\end{array}$ \\
\hline$O S S_{i t} / 100$ & $\begin{array}{c}3.6403 * * * \\
(0.3623)\end{array}$ & $\begin{array}{c}3.4451 * * * \\
(0.8938)\end{array}$ \\
\hline$\Delta O S S_{i t} / 100$ & $\begin{array}{c}-1.2756 * * * \\
(0.3977)\end{array}$ & $\begin{array}{c}-2.6233 * * * \\
(0.7877)\end{array}$ \\
\hline$O^{O S M_{i t}} / 100$ & $\begin{array}{c}-0.3950 \text { *** } \\
(0.1218)\end{array}$ & $\begin{array}{c}-0.2691 * * \\
(0.1265)\end{array}$ \\
\hline$\Delta \mathrm{OSM}_{i t} / 100$ & $\begin{array}{c}-1.4274 * * * \\
(0.2272)\end{array}$ & $\begin{array}{c}-0.4414 \\
(0.2806)\end{array}$ \\
\hline $\ln K_{i t}$ & $\begin{array}{c}0.0034 \\
(0.0139)\end{array}$ & $\begin{array}{c}0.0190 \\
(0.0274)\end{array}$ \\
\hline$\Delta \ln K_{i t}$ & $\begin{array}{c}0.1195 * * * \\
(0.0444)\end{array}$ & $\begin{array}{c}0.1769 * * \\
(0.0706)\end{array}$ \\
\hline
\end{tabular}

Joint tests (Wald):

\begin{tabular}{|c|c|c|}
\hline $\ln L_{i t-1}=1$ & $\begin{array}{c}\chi^{2}(1)=41.51 \\
p \text {-value }=0.0000\end{array}$ & $\begin{array}{c}\chi^{2}(1)=27.72 \\
p \text {-value }=0.0000\end{array}$ \\
\hline $\ln w_{i t}+\ln w_{i t-1}=0$ & $\begin{array}{c}\chi^{2}(1)=26.63 \\
p \text {-value }=0.0000\end{array}$ & $\begin{array}{c}\chi^{2}(1)=13.08 \\
p \text {-value }=0.0003\end{array}$ \\
\hline$O S S_{i t}+O S S_{i t-1}=0$ & $\begin{array}{c}\chi^{2}(1)=100.90 \\
p \text {-value }=0.0000\end{array}$ & $\begin{array}{c}\chi^{2}(1)=14.85 \\
p \text {-value }=0.0001\end{array}$ \\
\hline$O S M_{i t}+O S M_{i t-1}=0$ & $\begin{array}{c}\chi^{2}(1)=10.50 \\
p \text {-value }=0.0012\end{array}$ & $\begin{aligned} \chi^{2}(1) & =4.52 \\
p \text {-value } & =0.0334\end{aligned}$ \\
\hline $\ln K_{i t}+\ln K_{i t-1}=0$ & $\begin{aligned} \chi^{2}(1) & =0.06 \\
p \text {-value } & =0.8037\end{aligned}$ & $\begin{array}{c}\chi^{2}(1)=0.4801 \\
p \text {-value }=0.4884\end{array}$ \\
\hline Sargan test: & $\begin{aligned} \chi^{2}(37) & =58.45 \\
p \text {-value } & =0.0137\end{aligned}$ & $\begin{aligned} \chi^{2}(37) & =49.68 \\
p \text {-value } & =0.0793\end{aligned}$ \\
\hline m2 test: & $\begin{array}{c}\mathrm{z}=-0.21 \\
\text { p-value }=0.8265\end{array}$ & $\begin{array}{c}\mathrm{z}=-3.19 \\
\text { p-value }=0.0015\end{array}$ \\
\hline Period dummies & No & Yes \\
\hline s.e. & 0.0439 & 0.0418 \\
\hline Adj. $\mathbf{r}^{2}$ & 0.9433 & 0.9486 \\
\hline observations & 1743 & 1743 \\
\hline
\end{tabular}

Note: estimation based on equation (9) using the GMM-Arellano-Bover (1995) estimator in orthogonal deviations. Standard errors in parentheses. 


\section{Table A17: Total factor productivity}

Whole economy (83 industries)

Dependent variable: $\Delta \ln T F P_{i t}$

\begin{tabular}{|c|c|c|c|c|}
\hline & \multicolumn{2}{|c|}{ value-added-based } & \multicolumn{2}{|c|}{ gross output-based } \\
\hline & GMM & GMM & GMM & GMM \\
\hline$\Delta \ln T F P_{i t-1}$ & $\begin{array}{c}0.0938 * * * \\
(0.0103)\end{array}$ & $\begin{array}{c}0.0965 * * * \\
(0.0140)\end{array}$ & $\begin{array}{c}0.0482 * * * \\
(0.0104)\end{array}$ & $\begin{array}{c}0.0414 * * \\
(0.0171)\end{array}$ \\
\hline$O S S_{i t} / 100$ & $\begin{array}{c}1.2741 * * \\
(0.5351)\end{array}$ & $\begin{array}{c}0.8584 \\
(0.9567)\end{array}$ & $\begin{array}{c}1.4237 * * * \\
(0.5342)\end{array}$ & $\begin{array}{c}0.0692 \\
(0.5810)\end{array}$ \\
\hline$\Delta O S S_{i t} / 100$ & $\begin{array}{c}3.5201 * * \\
(1.3816)\end{array}$ & $\begin{array}{c}-9.1400 * * * \\
(3.5329)\end{array}$ & $\begin{array}{c}6.1018 * * * \\
(1.2103)\end{array}$ & $\begin{array}{l}-2.7228 \\
(2.2241)\end{array}$ \\
\hline OSM $_{i t} / 100$ & $\begin{array}{c}-0.2426 * * \\
(0.1012)\end{array}$ & $\begin{array}{c}0.3582 * * \\
(0.1766)\end{array}$ & $\begin{array}{l}-0.0649 \\
(0.0962)\end{array}$ & $\begin{array}{l}0.3203^{*} \\
(0.1848)\end{array}$ \\
\hline$\Delta O S M_{i t} / 100$ & $\begin{array}{c}-4.9745 * * * \\
(0.5377)\end{array}$ & $\begin{array}{c}-4.0102 * * * \\
(0.8056)\end{array}$ & $\begin{array}{c}-2.8750 * * * \\
(0.3957)\end{array}$ & $\begin{array}{c}-2.7278 * * * \\
(0.6282)\end{array}$ \\
\hline
\end{tabular}

Joint tests (Wald):

\begin{tabular}{ccccc}
\hline $\boldsymbol{O S S}_{i t}+\boldsymbol{O S S}_{\text {it-1 }}=\mathbf{0}$ & $\chi^{2}(1)=5.66$ & $\chi^{2}(1)=0.80$ & $\chi^{2}(1)=7.10$ & $\chi^{2}(1)=0.01$ \\
& $p$-value $=0.0173$ & $p$-value $=0.3696$ & $p$-value $=0.0077$ & $p$-value $=0.9052$ \\
$\boldsymbol{O S M}_{i t}+\boldsymbol{O S M}_{i t-1}=\mathbf{0}$ & $\chi^{2}(1)=5.74$ & $\chi^{2}(1)=4.11$ & $\chi^{2}(1)=0.45$ & $\chi^{2}(1)=3.00$ \\
& $p$-value $=0.0165$ & $p$-value $=0.0426$ & $p$-value $=0.5001$ & $p$-value $=0.0831$
\end{tabular}

\begin{tabular}{lcccc} 
Sargan test: & $\chi^{2}(41)=55.15$ & $\chi^{2}(41)=48.57$ & $\chi^{2}(41)=59.85$ & $\chi^{2}(41)=45.49$ \\
& $p$-value $=0.0689$ & $p$-value $=0.1941$ & $p$-value $=0.0287$ & $p$-value $=0.2903$ \\
m2 test: & $\mathrm{z}=-10.08$ & $\mathrm{z}=0.94$ & $\mathrm{z}=-8.85$ & $\mathrm{z}=-0.69$ \\
& $p$-value $=0.0000$ & $p$-value $=0.3426$ & $p$-value $=0.0000$ & $p$-value $=0.4891$ \\
Period dummies & no & yes & no & yes \\
s.e. & 0.0810 & 0.0842 & 0.0679 & 0.0581 \\
observations & 1743 & 1743 & 1743 & 1743 \\
\hline
\end{tabular}




\section{Appendix B: The Translog Cost Function}

First moves towards laying a suitable framework for offshoring are found in the cost function originally proposed by Berman et al. (1994). Typically assuming a translog cost function where firms minimize costs in choosing their inputs, the next step is to derive and estimate a factorshare equation. The translog, or transcendental logarithmic function, is basically a standard specification for modeling cost and production functions allowing for very flexible functional forms. Generally, with $C$ being total costs, $x$ a vector of prices of multiple inputs $(q)$, and $y$ a vector of the given levels of multiple outputs, we have:

$$
\begin{aligned}
& C(x, y)=\min _{q} x q \\
& \text { s.t. } q \in Z(y)
\end{aligned}
$$

with $Z(y)$ the total input requirements for the given $y^{\prime} s$. In this way, the translog function takes the form:

$$
\begin{aligned}
\ln C(x, y)= & \alpha_{0}+\sum_{i}^{m} \alpha_{i} \ln y_{i}+\sum_{i}^{n} \beta_{i} \ln x_{i} \\
& +\frac{1}{2} \sum_{i}^{m} \Sigma_{j}^{n} \alpha_{i j} \ln y_{i} \ln y_{j}+\frac{1}{2} \Sigma_{i}^{m} \sum_{j}^{n} \beta_{i j} \ln x_{i} \ln x_{j}+\Sigma_{i}^{m} \Sigma_{j}^{n} \gamma_{i j} \ln y_{i} \ln x_{j}
\end{aligned}
$$

which is an extension or more general expression of the Cobb-Douglas (cost) function. ${ }^{29}$ The first line of (B1) is none other than the Cobb-Douglas, while the second line allows for wider substitution possibilities between inputs and outputs. Using Shephard's lemma, first differentiating the cost function yields the share cost equation for each input. Specifically, the lemma states that if $C(x, y)$ is differentiable, there is a unique vector $S$ such that $\frac{\partial c(x, y)}{\partial x_{i}}=S_{i}$. From (B1) can be obtained:

$$
\frac{\partial C(x, y)}{\partial x_{i}}=S_{i}=\frac{x_{i} q_{i}}{C}=\beta_{i}+\sum_{j}^{n} \beta_{i j} \ln x_{j}+\sum_{i}^{m} \gamma_{i j} \ln y_{j}
$$

This specification is further augmented with other control variables, the offshoring index being one among them, and Feenstra and Hanson's being especially of widespread use. Particularly, the index aims to capture the elasticity of substitution of domestic value added in relation to imported intermediate inputs. A common representation for the industry, as found for instance in Berman et al. (1994) and Feenstra and Hanson (1996a, 1996b, 1999), would be something like:

$$
\Delta S_{i t}^{*}=\beta_{0}+\beta_{1} \Delta\left(O S_{i t}\right)+\beta_{2} \Delta \ln \left(y_{i t}\right)+\beta_{3} \Delta \ln \left(k_{i t}\right)+\beta_{4} \Delta\left(Z_{i t}\right)
$$

which is usually a regression of the change in the share of nonproduction wages in the industry's wage bill $\left(S_{i t}^{*}\right)$ on the structural (output and capital, among others) and control variables. Nonproduction and production labor are usually used as proxies of skilled and non-skilled employment. Through this it is possible to analyze the effects of offshoring on the relative changes between two (or more) skills of labor. Provided there are only two levels of skills which are identified, a second equation would be redundant.

${ }^{29}$ Also, a second order Taylor's series expansion of certain function, in this case a cost function. 


\section{References}

Agnese, P. and H. Sala (2008), "The fading 1990s in Japan: Driving forces behind the unemployment upsurge," International Review of Economics and Finance, doi: 10.1016/j.iref.2008.09.005.

Ahearne, A., and N. Shinada (2005), "Zombie firms and economic stagnation in Japan," International Economics and Economic Policy, 2 (4), pp. 363-381.

Ahn, S., and H. Moon (2001), "Large-N and Large-T Properties of Panel Data Estimators and the Hausman Test," mimeo.

Amiti, M. and S-J. Wei (2005), "Fear of service outsourcing: Is it justified?," Economic Policy, 20 (42), pp. 308-347.

Amiti, M. and S-J. Wei (2006), "Service offshoring, productivity, and employment: Evidence from the United States," CEPR Discussion Paper 5475.

Arellano, M. and S. Bond (1991), "Some Tests of Specification for Panel Data: Monte Carlo Evidence and an Application to Employment Equations," Review of Economic Studies, 58 (2), pp. 277-297.

Arellano, M. and O. Bover (1995), "Another look at the instrumental variable estimation of error-components models," Journal of Econometrics, 68 (1), pp. 29-51.

Arndt, S. (1997), "Globalization and the Open Economy," North American Journal of Economics and Finance, 8 (1), pp. 71-79.

Arndt, S. (1998), "Super-specialization and the gains from trade," Contemporary Economic Policy, 16 (4), pp. 480-485.

Arndt, S. (1999), "Globalization and economic development," Journal of International Trade and Economic Development 8 (3), pp. 309-318.

Arrow, K., H. Chenery, B. Minhas, and R. Solow (1961), "Capital-Labor Substitution and Economic Efficiency,” Review of Economics and Statistics, 63 (3), pp. 225-250.

Barro, R. and X. Sala i Martín, (2003), “Economic Growth,” The MIT Press.

Berman, E., J. Bound, and Z. Griliches (1994), "Changes in the Demand for Skilled Labor within U.S. Manufacturing: Evidence from the Annual Survey of Manufacturers," The Quarterly Journal of Economics, 109 (2), pp. 367-397.

Bond, S. (2002), "Dynamic panel data models: a guide to micro data methods and practice," Cemmap Working Paper Series CWP09/02.

Caballero, R., T. Hoshi, and A. Kashyap (2008), "Zombie lending and depressed restructuring in Japan," The American Economic Review, 98 (5), pp. 1943-1977.

Cadarso, M., N. Gómez, L. López, and M. Tobarra (2008), "The EU enlargement and the impact of outsourcing on industrial employment in Spain, 1993-2003," Structural Change and Economic Dynamics, 19 (1), pp. 95-108. 
Campa, J. and L. Goldberg (1997), "The evolving external orientation of manufacturing industries: Evidence from four countries," Federal Reserve Bank of New York Economic Policy Review, 4, pp. 79-99.

Canals, C. (2006), "What explains the widening wage gap? Outsourcing vs. technology," La Caixa Working Paper Series 01/2006.

Crinò, R. (2007), "Service offshoring and white-collar employment," CESifo Working Paper 2040.

Criscuolo, C. and M. Leaver (2005), "Offshore Outsourcing and Productivity," available at: www.oecd.org/dataoecd/55/23/35637436.pdf

Egger, H. and P. Egger (2003), "Outsourcing and skill-specific employment in a small economy: Austria after the fall of the Iron Curtain,” Oxford Economic Papers, 55 (4), pp. 625-643.

Egger, H. and P. Egger (2005), "Labor market effects of outsourcing under industrial interdependence," International Review of Economics and Finance, 14 (3), pp. 349-363.

Egger, P., F. Pfaffermayr, and A. Weber (2003), "Sectoral Adjustment of Employment: The Impact of Outsourcing and Trade at the Micro Level," Institute for Advanced Studies, Vienna, Economics Series, 145.

Ekholm, K. and K. Hakkala (2006), "The Effect of Offshoring on Labor Demand: Evidence from Sweden," The Research Institute of Industrial Economics Working Paper 654.

Feenstra, R. and G. Hanson (1996a), "Foreign investment, outsourcing, and relative wages," in: R. Feenstra, G. Grossman, and D. Irwin (eds.), The political economy of trade policy: Papers in honor of Jagdish Bhagwati, MIT Press, Cambridge, MA, pp. 89-127.

Feenstra, R. and G. Hanson (1996b), "Globalization, outsourcing, and wage inequality," The American Economic Review, 86 (2), pp. 240-245.

Feenstra, R. and G. Hanson (1997), "Foreign direct investment and relative wages: Evidence from Mexico's maquiladoras, Journal of International Economics, 42 (3/4), pp. 371-393.

Feenstra, R. and G. Hanson (1999), "The impact of outsourcing and high-technology capital on wages: Estimates for the United States, 1979-1990, “The Quarterly Journal of Economics, 114 (3), pp. 907-940.

Feenstra, R. and G. Hanson (2001), "Global production sharing and rising inequality: A survey of trade and wages," NBER Working Paper 8372, forthcoming, in: K. Choi and J. Harrigan (eds.), Handbook of International Trade, Basil Blackwell, Malden.

Forrester Research, 2004, “Near-term growth of offshoring accelerating," Cambridge, MA.

Fukao, M. (2003), “The Major Cause of the Long Recession is the Lack of Demand," in: K. Iwata and T. Miyagawa (eds.), What is the Real Cause of the Lost Decade, Toyo Keizai Shinpo Sha, Tokyo, pp. 17-20.

Fukao, K. and H. Kwon (2006), "Why did Japan's TFP growth slowdown in the lost decade? An empirical analysis based on firm-level data of manufacturing firms," The Japanese Economic Review, 57 (2). 
Fukao, K., T. Inui, H. Kawai, and T. Miyagawa (2004), "Sectoral Productivity and Economic Growth in Japan, 1970-1998: An Empirical Analysis Based on the JIP Database," in: T. Ito and A. K. Rose (eds.), Growth and Productivity in East Asia, National Bureau of Economic Research-East Asia Seminar on Economics, Vol. 13, University of Chicago Press, Chicago, pp. 177-227.

Fukao, K., S. Hamagata, T. Inui, K. Ito, H. Kwon, T. Makino, T. Miyagawa, Y. Nakanishi, and J. Tokui (2007), "Estimation Procedures and TFP Analysis of the JIP Database 2006," RIETI Discussion Paper 07-E-003.

Geishecker, I. and H. Görg (2005), "Do unskilled workers always lose from fragmentation?," North American Journal of Economics and Finance, 16 (1), pp. 81-92.

Girma, S. and H. Görg (2004), "Outsourcing, Foreign Ownership, and Productivity: Evidence from UK Establishment-level Data,” Review of International Economics, 12 (5), pp. 817-832.

Görg, H. and A. Hanley (2005), "Labour demand effects of international outsourcing: Evidence from plant-level data," International Review of Economics and Finance, 14 (3), pp. 365-376.

Griliches, Z. (1996), “The Discovery of the Residual: A Historical Note," Journal Economic Literature, 34 (3), pp. 1324-1330.

Hakkala, K., F. Heyman, and F. Sjöholm (2007), “Cross-Border Acquisitions, Multinationals and Wage Elasticities,” IFN Working Paper 709.

Hamermesh, D. (1993), “Labour Demand,” Princeton University Press, Princeton, NJ.

Hattori, T. and H. Miyazaki (2000), "Measuring Technological Progress and Factor Analysis of Economic Growth in Japanese Industry,” Denryoku Keizai Kenkyu, Vol. 44, pp. 1-16.

Hayashi, F. and E. Prescott (2002), "The 1990s in Japan: A lost decade," Review of Economic Dynamics, 5, pp. 206-235.

Head, K. and J. Ries (2002) "Offshore production and skill upgrading by Japanese manufacturing firms," Journal of International Economics, 58 (1), pp. 81-105.

Hicks, J. (1939), "Value and Capital: An inquiry into some fundamental principles of economic theory," Clarendon Press, Oxford.

Hijzen, A., H. Görg, and R. Hine (2005), "International outsourcing and the skill structure of labour demand in the United Kingdom,” The Economic Journal, 115, pp. 860-878.

Hijzen, A., I. Tomohiko, and Y. Todo (2006), "Does Offshoring Pay? Firm-Level Evidence from Japan,” RIETI Discussion Paper 07-E-005.

Horgos, D. (2008), "Labor market effects of international outsourcing: how measurement matters," International Review of Economics and Finance, forthcoming; doi: 10.1016/j.iref.2008.10.006.

Hsiao, C. (2003), “Analysis of Panel Data,” Cambridge University Press.

Hulten, C. (2001), “Total factor productivity: a short biography," in: Hulten, Dean and Harper (eds.), 2001, Journal New Development in Productivity Analysis, University of Chicago Press for the National Bureau of Economic Research. 
Hummels, D., J. Ishii, and K-M. Yi (2001), "The Nature and Growth of Vertical Specialization in World Trade," Journal of International Economics, 54 (1), pp. 75-96.

Ito, B., E. Tomiura and R. Wakasugi (2007)," Dissecting Offshore Outsourcing and R\&D: A Survey of Japanese Manufacturing Firms, RIETI Discussion Paper 07-E-060.

JIP Database (2006, 2008), RIETI, Hitotsubashi University, and ESRI, Japan.

Kee, H. (2004), "Estimating Productivity When Primal and Dual TFP Accounting Fail: An Illustration Using Singapore's Industries," Topics in Economic Analysis and Policy, 4 (1).

Kirkegaard, J. (2007), "Offshoring, outsourcing, and production relocation. Labor market effects in the OECD countries and developing Asia," IIE Working Paper 07-02.

Kobayashi, K. (2007), "Payment uncertainty and the productivity slowdown," Macroeconomic Dynamics, 11 (2), pp. 231-248.

Krugman, P. (1995), “Growing World Trade: Causes and Consequences," Brookings Papers on Economic Activity, 1.

Krugman, P. (2000), “Technology, trade, and factor prices," Journal of International Economics, 50 (1), pp. 51-71.

Lawrence, R., M. Slaughter, and R. Hall (1993), "International Trade and American Wages in the 1980s: Giant Sucking Sound or Small Hiccup?," Brookings Papers on Economic Activity, 1, pp. 161-226.

Leamer, E. (1994), “Trade wages and revolving door ideas,” NBER Working Paper 4716.

Leamer, E. (1998), "In Search of Stolper-Samuelson Linkages between International Trade and Lower Wages," in: Susan M. Collins (ed.), Imports, Exports, and the American Worker, Brookings Institution, Washington, DC, pp. 141-203.

McKinsey Global Institute (2003), “Who wins in offshoring,” The McKinsey Quarterly, 4.

Miyagawa, T. (2003), "The Lost Decade and Structural Change," in: K. Iwata and T. Miyagawa (eds.), What is the Real Cause of the Lost Decade, Toyo Keizai Shinpo Sha, Tokyo, pp. 39-61.

Miyagawa, T., Y. Sakuragawa, and M. Takizawa (2006), "Productivity and business cycles in Japan: evidence from Japanese industry data,” The Japanese Economic Review, 57 (2).

OECD (2007), "Offshoring and Employment. Trends and impacts."

Olsen, K. (2006), "Productivity Impacts of Offshoring and Outsourcing: A Review," OECD STI Working Paper 2006/1.

Samuelson, P. (1947), "Foundations of Economic Analysis," Harvard University Press, Cambridge, Mass.

Shephard, R. (1953), "Theory of Cost and Production Functions," Princeton University Press, Princeton, NJ.

Siegel, D. and Z. Griliches (1992), "Purchased services, outsourcing, computers, and productivity in manufacturing," in Z. Griliches, E.R. Berndt, T.F. Bresnahan and M.E. Manser (eds.), Output Measurement in the Service Sectors, National Bureau of Economic Research (NBER) 
Studies in Income and Wealth 56, The University of Chicago Press: Chicago, IL, pp. 429460.

Slaughter, M. (1995), "Multinational Corporations, Outsourcing, and American Wage Divergence,” NBER Working Paper 5253.

Slaughter, M. (2000), "Production transfer within multinational enterprises and American wages," Journal of International Economics, 50 (2), pp. 449-472.

Strauss-Kahn, V. (2004), "The role of globalization in the within-industry shift away from unskilled workers in France," in: R. Baldwin and A. Winters (eds.), Challenges to Globalization, University of Chicago Press: Chicago.

Tomiura, E. (2005), "Foreign outsourcing and firm-level characteristics: Evidence from Japanese manufacturers," Journal of the Japanese International Economics, 19 (2), pp. 255-271.

Van Beveren, I. (2007), "Total factor productivity estimation: A practical review," LICOS Discussion Paper 182.

Wakita, S. (2006), “The Lost Decade in the Japanese Labor Market: Labor's share and Okun's Law, Public Policy Review, 2 (1), pp. 77-96.

Webster, E. (2003), "The Effects of Wages on Aggregate Employment: A Brief Summary of Empirical Studies," The Australian Economic Review, 36 (1), pp. 134-142.

Yoshikawa, H. (2003), “Comment on Hayashi Paper: Too Much is as Bad as Too Little?," in: K. Iwata and T. Miyagawa (eds.), What is the Real Cause of the Lost Decade, Toyo Keizai Shinpo Sha: Tokyo, pp. 21-24.

Yoshikawa, H., and K. Matsumoto, (2001), "An introduction: The Japanese and the U.S. Economy in the 1990s," Financial Review, 58, pp. 1-17.

Zheng, S. (2005), "Estimating Industry Level Multifactor Productivity: Methods and Experimental Results," ABS Working Paper (1351.055.004). 